\title{
A Systems Approach to Developing an Affordable Space Ground Transportation Architecture using a Commonality Approach
}

\author{
Jerry L. Garcia*, Carey M. McCleskey ${ }^{\dagger}$, Timothy R. Bollo ${ }^{\ddagger}$ and Russel E. Rhodes (ret.) ${ }^{\S}$ \\ NASA Kennedy Space Center, Florida, 32899 \\ And \\ John W. Robinson ${ }^{* *}$ \\ Propellant Supply Technology, Seal Beach, California, 90740
}

\begin{abstract}
With better than 20 years' experience, the von Braun team preached and practiced that rocket and launch pad must be mated on the drawing board, if they were to be compatible at the launching. The new rocket went hand in hand with its launching facility.
\end{abstract}

Moonport (NASA SP-4204)

C. D. Benson \& W. B. Faherty

1978

This paper presents a structured approach for achieving a compatible Ground System (GS) and Flight System (FS) architecture that is affordable, productive and sustainable. This paper is an extension of the paper titled "Approach to an Affordable and Productive Space Transportation System" by McCleskey et al. ${ }^{1}$ This paper integrates systems engineering concepts and operationally efficient propulsion system concepts into a structured framework for achieving GS and FS compatibility in the mid-term and long-term time frames. It also presents a functional and quantitative relationship for assessing system compatibility called the Architecture Complexity Index (ACI). This paper: (1) focuses on systems engineering fundamentals as it applies to improving GS and FS compatibility; (2) establishes mid-term and long-term spaceport goals; (3) presents an overview of transitioning a spaceport to an airport model; (4) establishes a framework for defining a ground system architecture; (5) presents the ACI concept; (6) demonstrates the approach by presenting a comparison of different GS architectures; and (7) presents a discussion on the benefits of using this approach with a focus on commonality.

I. Nomenclature

\begin{tabular}{|l|l|}
\hline$A C I=$ architectural complexity index & $L O_{2}=$ liquid oxygen \\
\hline$C E T=$ central external tank & $L O I=$ launch operability index \\
\hline$F S=$ flight system & $L R U=$ line replace units \\
\hline $\mathrm{GS}=$ ground system & $\mathrm{N}_{2}=$ nitrogen \\
\hline$H e=$ helium & $P / L=$ payload \\
\hline$L C, S L C=$ launch complex; also, space launch complex & $R C B=$ Reusable Cryogenic Booster \\
\hline$L H_{2}=$ liquid hydrogen & $R C O=$ Reusable Cryogenic Orbiter \\
\hline
\end{tabular}

* Aerospace Technologist, Engineering and Technology Directorate, NASA Kennedy Space Center, mail code NE-D3

${ }^{\dagger}$ Aerospace Technologist, Engineering and Technology Directorate, NASA Kennedy Space Center, mail code NE-D3; AIAA

Senior Member.

${ }^{\ddagger}$ Aerospace Technologist, Engineering and Technology Directorate, NASA Kennedy Space Center, mail code NE-OO

${ }^{\S}$ Aerospace Technologist, NASA Kennedy Space Center, retired, and AIAA Senior Member.

${ }^{* *}$ Propellant Supply Technology; chairman, Space Propulsion Synergy Team, and AIAA Associate Fellow. 


\section{Introduction}

$\mathrm{T}$ he traditional approach to developing ground systems architecture begins with the development of the flight system (FS) architecture followed by the ground systems (GS) architecture with a heavy emphasis on achieving flight performance requirements and meeting non-recurring budgets. This approach, heavily utilized since the 1960 's, yields space transportation systems that are neither affordable nor sustainable. ${ }^{2,3}$ This paper presents a structured systems engineering approach for achieving a compatible ground system and flight system architecture that is affordable and sustainable while achieving mission performance requirements. The approach integrates space flight systems engineering concepts and operationally efficient propulsion system concepts into a framework for assessing space transportation system complexity and affordability. It presents key architectural decisions that yield the identification of required ground system services. The ground services information is then used to establish a functional and quantitative assessment that measures the overall complexity. This measure is called the Architecture Complexity Index (ACI). The ACI was derived from the Launch Operational Index (LOI) as described in the Operationally Efficient Propulsion Systems Study (OEPSS). ${ }^{4}$

This paper addresses the following five problems when developing affordable space transportation system architecture:

P-1: There are no structured and reliable approaches for developing an affordable ground system that is compatible with the flight system.

P-2: There are no common industry standards between the spaceport and the vehicle.

P-3: There are no universal standards between spaceports and between vehicles.

P-4: There are no standard measures for assessing grounds system complexity.

P-5: There are no standard approaches to developing an architecture that services multiple vehicles from the same spaceport with shared resources and from the same launch point affordably.

This paper presents a structured approach for solving these problems by addressing the following topics: spaceport concepts; establishing spaceport mid-term and long-term goals; an overview of transitioning a spaceport to an airport model; presenting a process for defining a ground systems architecture; presenting an index for assessing architecture complexity and relating it to affordability; demonstrating the concept by comparing three ground system architectures; and finally, presenting how commonality can help reduce these problems.

\section{Systems Engineering Perspective}

\section{A. Key Concepts and Definitions}

1. AFFORDABILITY - is a characteristic of a capability that is a measure of what you have (e.g., time, money) vs. your ability to bear the cost. If at any time during the life cycle, affordability is exceeded, the system cannot be sustained.

2. ARCHITECTURE - is the orderly arrangement of functions, operations, physical entities, and business models in support of a mission. ${ }^{6}$ There are four views to architecture:

- Functional view addresses the actions required, and takes on the form of verb plus noun

- Operational view focuses on the execution of the functions using the physical assets within the architecture.

- Physical view refers to the infrastructure, facilities, and equipment required for supporting a particular function.

- Business view represents the approach of how an organization creates, delivers and captures value (benefit/investment). 
Figure-1 illustrates this definition and its relationships. The intersections of the Functions, Operations, Physical Assets, and the Business Model represent the Architecture capabilities (collection of services).

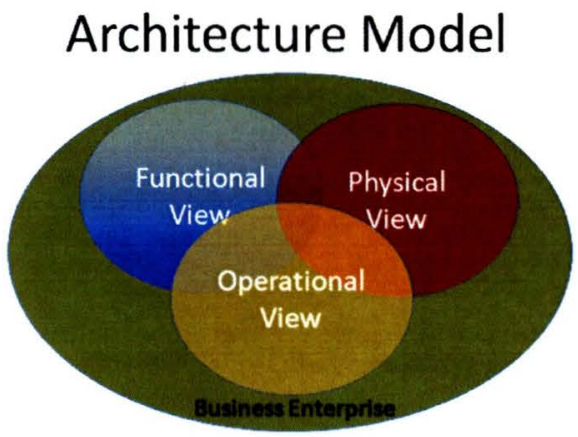

Figure-1: A Systems Perspective of an Architecture Model

3. AVAILABILTY - is the probability that a repairable system is operational at the precise time needed'. It is solely based on the failure (reliability) distribution and the downtime (maintainability) distribution. The equation for Inherent Availability, Ai, is

$$
A i=M T B F /(M T B F+M T T R)
$$

where $M T B F$ is mean time between failure (i.e., the average time the system performs its intended function) and MTTR is the mean time to repair (i.e., the time to identify and access the failed article, repair or replace the article, and verify the functionality of the repaired system.)

4. CAPABILITY - is the ability to perform a service at a specific performance level. The intersection of functions, operations, physical entities, and business model yields a capability. A capability has 6 basic characteristics: performance, affordability, value, responsiveness, availability, and risk \& safety.

5. COMMONALITY is the sharing of characteristics or configurations between and within entities for the purpose of improving economic, reliability, and logistic objectives.

6. COMPATIBILITY is the orderly, efficient integration and operation with other systems with no modification or conversion required. ${ }^{8}$

7. MAINTENANCE is the functions and activities associated with sustaining a capability in the operational state. There are three levels of maintenance: Flight Line Level (at Launch Pad operations) maintenance, Intermediate Level (minor overall operations) maintenance and Depot Level (major overhaul) maintenance.

8. PRODUCTIVENESS \& PRODUCTIVITY - Productiveness is the effectiveness of what the system produces on a regular basis. For space transportation it may be measured in space flights per unit time, or in terms of throughput (annual payload mass delivered, annual seats provided, etc.). Productivity is the efficiency with which a given level of production is obtained. It is measured by the production level output (productiveness) relative to the input (an organization's labor level, for example)

9. SERVICE is the functions, assets, and operations associated with fulfilling a need. The quality of service (QoS) can be assessed in a few dimensions such as product quality, cost, responsiveness, complexity, completeness, and inherent availability.

10. SPACEPORT is an entity that provides the essential capabilities to support spaceflight departures, arrivals, production and sustainment. ${ }^{10}$ A spaceport has at least one launch complex and its supporting infrastructure.

11. STATION SET is the accumulation of facilities, equipment and/or operations to perform a service(s) at a spaceport. ${ }^{\text {II }}$ Figure-2 illustrates the characteristics of a station set.

American Institute of Aeronautics and Astronautics 08012012 


\section{Station Set Characteristics}

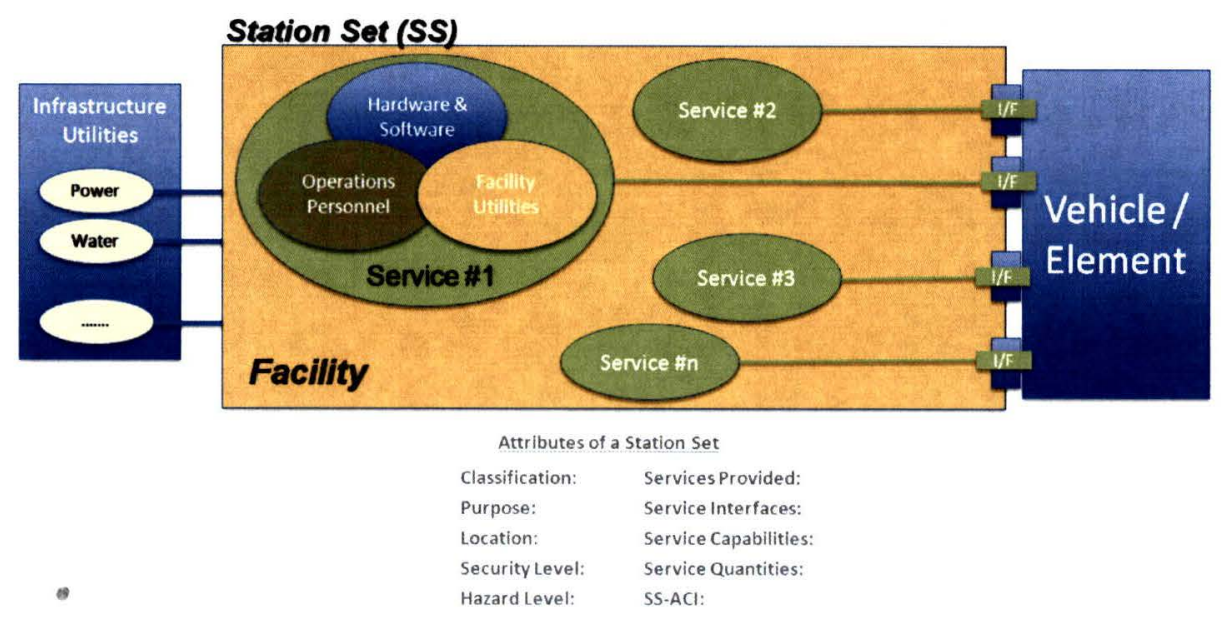

Figure-2: Station Set Characteristics

\section{B. Spaceport Concepts}

Spaceport is an entity that provides the essential capabilities to support spaceflight departures, arrivals, production and sustainment. The goal of the spaceport is to operate "like an airport and as a business." 12 The spaceport has several members: spaceport operator, launch vehicle operator, payload customer and possibly launch vehicle manufacturer. In the future, the spaceport operator will be challenged to provide more than just the land, facilities, and launch site infrastructure but also to accommodate supporting multiple launch vehicles, launching them from the same launch point and to do it affordably. ${ }^{13,14}$ Figure 3 shows basic spaceport functions. The spaceport functions are divided into six levels of operations: flight element operations; integrated operations; payload element operations; flight \& ground traffic control \& safety; landing \& recovery; and enabling operations. This paper focuses on the first three sets of operations. The functions identified are generic functions that all spaceport architectures must address during conceptual design. The collection of functions, operations and physical assets (hardware and software) formulate spaceport services. The most time consuming spaceport functions are assembling of flight elements (B1), servicing and checkout of flight elements (C1) and restore flight and ground system elements for reuse $(I 1 \& J) .{ }^{15}$ What differentiates one spaceport from another spaceport offering the same service is:

- Uniqueness of the flight vehicle architecture.

- Complexity of the services required to support the flight vehicle architecture.

- Volume of commodities required to support the service.

- Ordering/sequencing of the ground services.

- Organization of the ground services (physical location - station sets allocations).

- Geographic location 


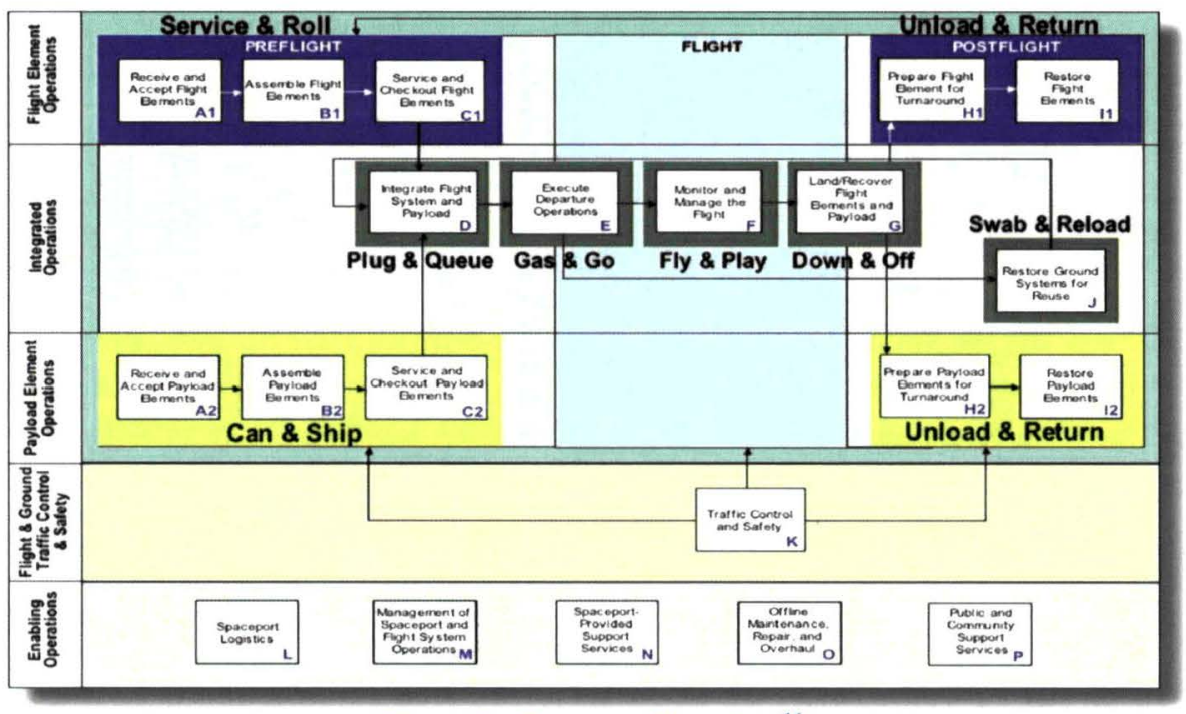

Figure 3 - Spaceport Functions ${ }^{16}$

\section{Transitioning a Spaceport to an Airport Model}

The increase of commercial interests as significant users has spurred a trend towards a very different launch site. In the past, a limited number of spaceports were devoted, for the most part, to government programs. The nature of these programs was that they were not open for public use, had tightly controlled contracts and excluded open commercial participation. That has changed. Currently, a multitude of spaceports are beginning to house a variety of programs, most of which are commercial and the commercial users are interested in profit. The spaceports are changing from a closed government launch complex to a profit-friendly multiple-user open launch complex. The spaceports are moving towards an airport model.

How do spaceports and airports compare? Both are involved in: ${ }^{17}$

- Dealing with strong interest by: different levels of government; general and specialinterest public; and a variety of commercial entities.

- Management of complex and expensive technical operations in a complex, large, and expensive infrastructure.

- Ensuring safety of their operations for themselves as well as the surrounding community.

- Offering services to competing entities that have invested vast amounts of money in their operations.

- Management and integration of competitors that share similar interests as well.

- Complex funding and business issues.

- Responding to different governmental agencies and different levels of government requirements that may conflict or compete.

- Maintaining good community relations.

- In competition with like enterprises.

Spaceports are becoming similar to airports, but there are significant and fundamental differences. Airports have

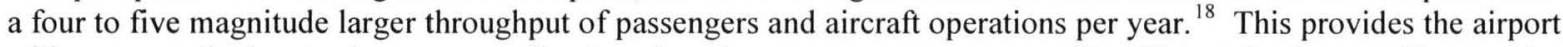
with comparatively steady revenue allowing the airport to operate as a self-sufficient business. Conversely, spaceports do not have this kind of revenue. Instead, the spaceport depends on small throughputs of less than a dozen missions per year. These missions are in many cases ultimately funded by the Federal Government, and to a smaller extent, commercial enterprises. This kind of revenue is not as steady or dependable and especially, it is difficult to forecast. So operating as a business is difficult, if not impossible. A second fundamental difference is 
that the operations at an airport are of low to moderate technical complexity, frequency, and participation in a mature transportation system. As a result, the users have commonly shared requirements/resources such as runways and terminals. Presently, all single point refueling connections are the same for airliners. In contrast, the operations at the spaceports are highly technical, high-risk and far less mature. This translates into a small number of expensive programs with unique configurations and fewer common requirements or shared resources. For example, each launch vehicle has its own, unique launch pad.

The spaceports may not achieve the high levels of passenger throughput or number of flights as an airport; however, the advantage airports have in being part of a mature transportation system in which standard configurations, consensus standards/specifications, and common shared infrastructure provides architectural inspiration. To reach an airport's greater level of utility, spaceports must embrace standard configurations and shared infrastructure. Commercial and governmental space industry must do this as a community. This could start immediately with a modest but significant effort to standardize flight to ground interfaces, for example, with a standardized LOX quick disconnect. Until this comes to fruition, the space transportation will not mature and the commercial viability of space will remain severely restricted.

\section{Spaceport Mid-term and Long-term Goals}

In the last 30 years NASA accomplished 135 missions to low Earth Orbit (LEO) using the Space Shuttle. It carried a very dedicated and massive ground systems infrastructure with an average cost of $\$ 200$ million to $\$ 450$ million per mission. ${ }^{19}$ The new challenge for NASA is to enable the transformation of a single use ground systems infrastructure into a more multi-use and affordable spaceport. ${ }^{20}$ To meet this challenge, this paper recommends the following Spaceport Vision:

\section{Spaceport Vision \\ Enabling affordable and routine access to space through \\ common services, standardized interfaces and simplified operations.}

By stressing the importance of common services, standardized interfaces and simplified operations, the following basic airport operational concepts, shown in Table-1, can be realized. ${ }^{21}$ (Note: these airport operational concepts are identified in boldface letters on Figure 3).

Table-1: Airport Operational Concepts

\begin{tabular}{|c|c|c|}
\hline Operation & Focus of Operation & Supporting Techniques \\
\hline $\begin{array}{l}\text { Service \& Roll } \\
\text { Operations }\end{array}$ & $\begin{array}{l}\text { Reducing preflight operations of each } \\
\text { element. }\end{array}$ & $\begin{array}{l}\text { - Minimal servicing (common services) } \\
\text { - Replenish consumables } \\
\text { - Integrated diagnostic testing within LRU's }\end{array}$ \\
\hline $\begin{array}{l}\text { Plug \& Queue } \\
\text { Capability }\end{array}$ & $\begin{array}{l}\text { Reducing integration and checkout time } \\
\text { of flight elements and payload. }\end{array}$ & $\begin{array}{l}\text { - Standardize interfaces } \\
\text { - Self aligning surfaces }\end{array}$ \\
\hline $\begin{array}{l}\text { Can \& Ship } \\
\text { Capability }\end{array}$ & $\begin{array}{l}\text { Reducing payload processing time at the } \\
\text { spaceport. }\end{array}$ & $\begin{array}{l}\text { - Self sufficient payloads (Containerized) } \\
\text { - Standardize interfaces to vehicle }\end{array}$ \\
\hline $\begin{array}{l}\text { Gas \& Go } \\
\text { Operations }\end{array}$ & Reducing the launch point stay time. & $\begin{array}{l}\text { - On-demand propellant servicing } \\
\text { - Quick verification of flight readiness }\end{array}$ \\
\hline $\begin{array}{l}\text { Down \& Off } \\
\text { Operations }\end{array}$ & $\begin{array}{l}\text { Reducing the time to recover and safe } \\
\text { flight elements. }\end{array}$ & $\begin{array}{l}\text { - Minimize hazardous servicing } \\
\text { - Integrated diagnostic testing }\end{array}$ \\
\hline $\begin{array}{l}\text { Unload \& Return } \\
\text { Capabilities }\end{array}$ & $\begin{array}{l}\text { Reducing the time to turnaround/restore } \\
\text { flight elements for launch. }\end{array}$ & $\begin{array}{l}\text { - Rapid payload removal. } \\
\text { - Easy to replace/repair LRU's }\end{array}$ \\
\hline $\begin{array}{l}\text { Swab \& Reload } \\
\text { Capabilities }\end{array}$ & $\begin{array}{l}\text { Reducing time and cost to restore ground } \\
\text { services for next launch. }\end{array}$ & $\begin{array}{l}\text { - Minimize hazardous commodity fallout } \\
\text { - Minimize environmental impacts } \\
\text { - Easy to repair/replace ground services } \\
\text { - Integrated ground self-verification services }\end{array}$ \\
\hline
\end{tabular}


These operational concepts can support the achievement of the mid-term and long-term spaceport goals as defined in Table- 2 and derived from the paper by McCleskey, et al. ${ }^{22}$

Table-2: Ground Systems Architecture Mid-term and Long-term Goals

\begin{tabular}{|l|l|c|c|}
\hline \multicolumn{1}{|c|}{ Goal Theme } & \multicolumn{1}{|c|}{ Goal Description } & Mid-term Goals & Long-term Goals \\
\hline Affordability Goal & $\begin{array}{l}\text { Provide a GS Architecture that supports life cycle } \\
\text { cost of less than: }\end{array}$ & $\$ 1,000 / \mathrm{lb}$ & $\$ 100 / \mathrm{lb}$ \\
\hline $\begin{array}{l}\text { Throughput Goal } \\
\text { (Productiveness) }\end{array}$ & $\begin{array}{l}\text { Provide a GS Architecture that supports throughput } \\
\text { per string of assets greater than: }\end{array}$ & $\begin{array}{c}\text { 500MT/year per } \\
\text { string of assets }\end{array}$ & $\begin{array}{c}1,000 \mathrm{MT} / \text { year per } \\
\text { string of assets }\end{array}$ \\
\hline
\end{tabular}

Spaceport architecture starts by having all stakeholders establish an overall spaceport vision and identifying Design Reference Markets (DRM). Architectural tenets should then be established so that they are aligned with the overall vision for the spaceport. These tenets define "what is valued by the spaceport architecture."

This paper recommends the following tenets against which any spaceport architecture should be evaluated:

\section{Spaceport Architecture Tenets}

Tenet-1: The spaceport architecture shall support multiple operators from the same spaceport.

Tenet-2: The spaceport architecture should complement the operator's business model.

Tenet-3: The spaceport architecture shall minimize operational constraints especially between operators.

Tenet-4: The spaceport architecture shall minimize operator-unique spaceport interfaces and dedicated infrastructure.

Tenet-5: The spaceport architecture shall promote commonality, standards, and simplified operations to increase flight rates and improve affordability.

\section{A Framework for Defining a Ground Systems Architecture Process}

\section{A. Overview of a Process for Defining a Ground Systems Architecture}

Figure 4 summarizes the process for defining ground systems architecture. Attachment-A shows the detailed process, which establishes a structured approach for developing a compatible ground system architecture and flight system architecture that is affordable, productive and sustainable. (Note: This process only focuses on the ground systems phase of the spaceflight life cycle.)

The process addresses four phases of the ground system life cycle: customer definition phase; launch definition phase; vehicle integration and checkout (I\&C) definition phase; and the manufacture element definition phase. The launch definition phase defines and assesses the vehicle types and launch point locations within the spaceport. The vehicle integration and checkout definition phase defines and assesses the vehicle launch configuration and its services at the launch point. The vehicle integration and checkout (I\&C) definition phase defines and assesses the integration and checkout vehicle methodology, the transportation method to launch point, and the launch point installation services. Finally, the recovery and manufacture element definition phase defines and assesses the recovery, manufacturing and/or refurbishment services for all elements and payloads. 


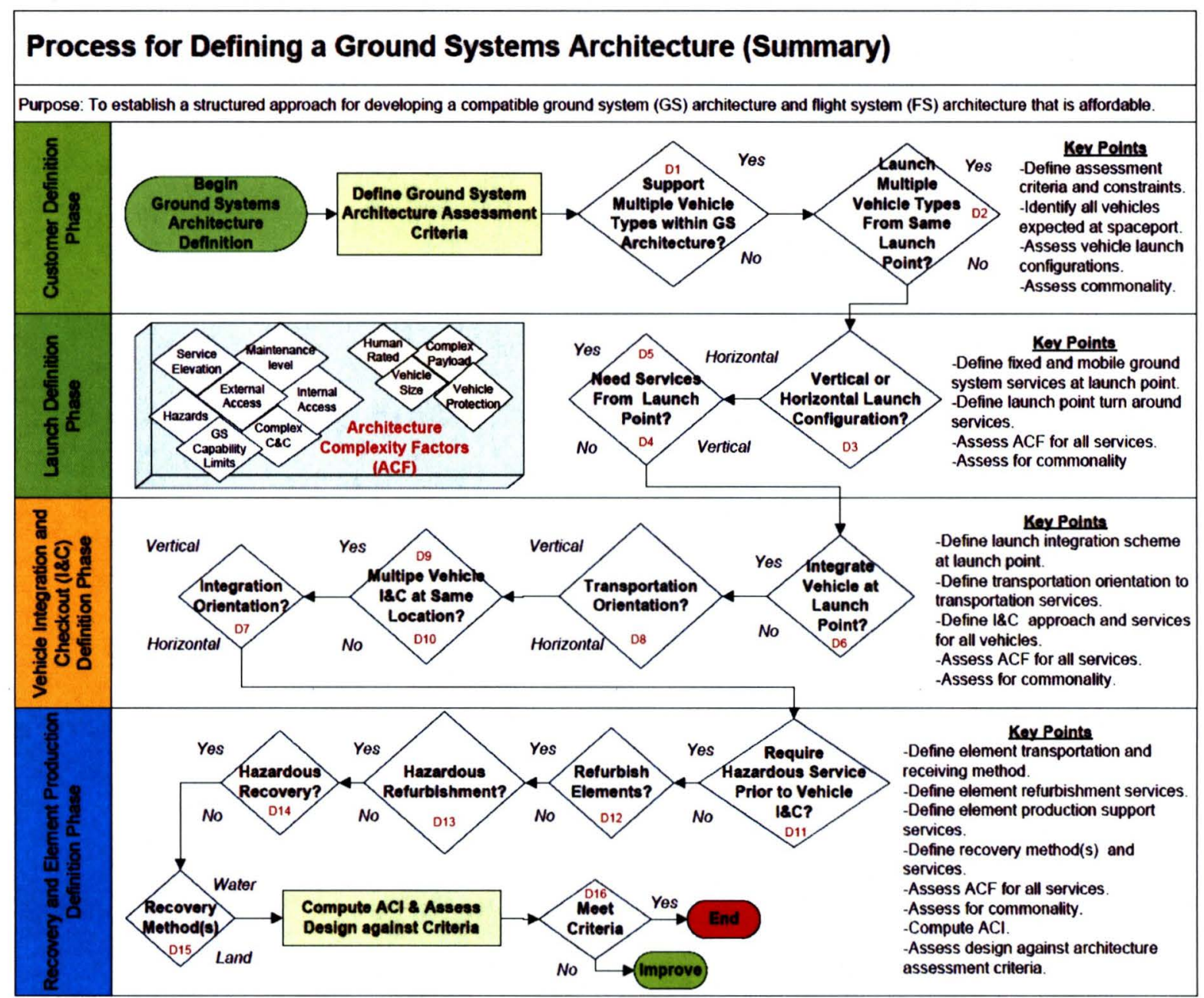

Figure 4: Process for Defining Ground Systems Architecture

The process as depicted in Figure 4 begins with defining the ground systems assessment criteria and identifying ground architecture constraints. The criteria establish a completion point for the process and the constraints establish the boundaries of the design. During each phase of the process, key decisions (represented by a diamond symbol in Figure 4) are made based on flight architecture and spaceport needs. These decisions identify the types of ground services (represented by key point comments or square boxes) required per phase and the complexity of ground service(s) required by the flight system throughout the lifecycle.

During any step or decision within this process, one or more trade studies may be conducted before a final decision about the final service characteristics can be made. Every service identified will be assessed based on a set of factors as shown in the large grey box in the launch definition phase of Figure 4 . These factors are called the Architecture Complexity Factors (ACFs). The seven fundamental factors that compose the index are shown in white. The other four factors are combinations of the seven fundamental ACFs. Details of the ACFs will be discussed in the architecture complexity index (ACI) section of this paper. This process primarily focuses on identifying key ground services and not specific design details about the hardware, software, or infrastructure. By addressing the ground architecture design at the services level, the ground and flight architecture are improved by the following approaches:

- Promote commonality (standard interfaces and common services) in all areas of the vehicle design and ground design, especially between the ground system and the vehicle interfaces. 
- Identify opportunities of improvement on the vehicle design that will reduce the number of ground services required and reduce the complexity of the ground services.

- Reduce the amount of time required to ground process a vehicle, e.g., improve throughput.

The Space Propulsion Synergy Team (SPST) developed a comprehensive space transportation systems breakdown structure (SBS) template that provides definitions of the essential ground system functions per phase to help facilitate this process. ${ }^{23}$ The identification of services establish the ground architecture capability level; that is, the quality and quantity of the service provided, the maturity of the organization's operations, and the availability of the hardware, software, and facilities needed to host these services. After identifying the required ground services and assessing their complexity (ACF), the architecture tenets are reviewed for compliance, the architecture is assessed for complexity using the Architecture Complexity Index (ACI), optimized for improvements and then are allocated to a station set. If the ground system architecture criteria are not satisfied, the process is repeated. Attachment-B identifies specific architectural decisions and potential architectural concerns that need to be addressed while following this architecture design process.

\section{Architecture Complexity Index (ACI)}

\section{A. Need for ACI}

To promote operational simplicity, an index of ground systems complexity is needed. The complexity index had to be quantifiable rather than subjective, applicable to all ground system services and spaceport architectures. The index had to assess key flight and ground ACFs. Note: ACI was derived from the Launch Operability Index $(\mathrm{LOI})^{24}$. Table 3 defines the complexity factors, the assessment focus and rationale. Attachment-C provides more details on these factors.

Table 3: Architecture Complexity Factor (ACF) Characteristics

\begin{tabular}{|c|c|c|}
\hline $\begin{array}{c}\text { Architecture } \\
\text { Complexity Factor }\end{array}$ & Assessment Focus & Rationale For Factor \\
\hline Service Elevation Factor & Assesses the vertical location of the service. & $\begin{array}{l}\text { The higher vertical location of the service requires } \\
\text { more infrastructure. This directly impacts the launch } \\
\text { tower size, service mast size, the number of platform } \\
\text { levels and type of crew ingress/egress. }\end{array}$ \\
\hline $\begin{array}{l}\text { External Outer Mold Line } \\
\text { (OML) Factor }\end{array}$ & $\begin{array}{l}\text { Assesses the complexity of the OML and } \\
\text { flight access points including integration of } \\
\text { elements and vehicle protection. }\end{array}$ & $\begin{array}{l}\text { The larger the vehicle size, number of elements, } \\
\text { complexity of integration of elements directly impacts } \\
\text { the size of integration facility, crane capabilities, } \\
\text { number of platform levels, and ground crew egress } \\
\text { requirements. }\end{array}$ \\
\hline Internal Access Factor & $\begin{array}{l}\text { Assesses the complexity of accessing internal } \\
\text { compartments. This includes human rated } \\
\text { vehicle compartments. }\end{array}$ & $\begin{array}{l}\text { Internal access directly impacts the amount of life } \\
\text { support conditioning (air purge), platform } \\
\text { requirements, and crew ingress/egress. }\end{array}$ \\
\hline Hazard Type Factor & Assesses the class of hazard related to service. & $\begin{array}{l}\text { The type of hazard directly impacts operational } \\
\text { sequencing, facility infrastructure, and level of } \\
\text { operator certification and the amount of safety } \\
\text { requirements and medical support. }\end{array}$ \\
\hline $\begin{array}{l}\text { Command \& Control } \\
\text { (C\&C) Type Factor }\end{array}$ & $\begin{array}{l}\text { Assesses the complexity of command and } \\
\text { control required to support service. }\end{array}$ & $\begin{array}{l}\text { The C\&C class directly impacts the amount of remote } \\
\mathrm{I} / \mathrm{O} \text {, the amount of software development, and the } \\
\text { amount of verification. }\end{array}$ \\
\hline $\begin{array}{l}\text { Maintenance Level Factor } \\
\text { (see Sect. III.A.7) }\end{array}$ & $\begin{array}{l}\text { Assesses the required maintenance level } \\
\text { required. }\end{array}$ & $\begin{array}{l}\text { The maintenance level directly relates to the amount } \\
\text { of infrastructure and maintenance time required. }\end{array}$ \\
\hline Capability Level Factor & $\begin{array}{l}\text { Assesses the capability of the ground system } \\
\text { to deliver the needed service (e.g., quantity of } \\
\text { a commodity) and its extensibility. }\end{array}$ & $\begin{array}{l}\text { Exceeding capability levels may require a interface } \\
\text { redesign, more infrastructure, more commodities, and } \\
\text { new equipment. }\end{array}$ \\
\hline
\end{tabular}

American Institute of Aeronautics and Astronautics 08012012 


\section{B. Description of ACI}

The key step in utilizing the ground systems architecture process is calculating the ACI. The ACI is a normalized parameter that relates flight system operability to ground systems efficiency and complexity. It provides a comparative metric for assessing different flight architectures to the overall GS architecture across the entire ground life cycle. The Launch Operations Index (LOI) should be used in conjunction with ACI to validate FS and GS compatibility and affordability. Each service is evaluated against ACFs. The first part of the index is computed by assigning a weighting factor to each complexity factor, assessing each service against each complexity factor, multiplying the weighting factor by the assessed service, summing all products, and then dividing by the maximum total possible ACF assessment. The weight factor ranks the importance of each complexity factor as a function of architecture tenets. Eq. (1) defines the architecture complexity factor of a service, $\mathrm{SACF}_{\mathrm{i}}$.

$$
S A C F_{i}=\frac{\sum_{k=1}^{7} W F_{k} \times A C F_{i, k}}{\sum_{k=1}^{7} W F_{k} \times \operatorname{MAX}\left(A C F_{i, k}\right)}
$$

where,

$$
\begin{aligned}
& \mathrm{WF}_{\mathrm{k}}=\text { the architecture complexity factor weight factor } \\
& \mathrm{ACF}_{\mathrm{i}, \mathrm{k}}=\text { the assessed service }(\mathrm{i}) \text { value for } \operatorname{ACF}(\mathrm{k}) \\
& i=\text { index number of the service } \\
& k=\text { architecture complexity factors index number (1 to 7) }
\end{aligned}
$$

The second part of the index involves allocating services to a station set. This allows for improvement and reuse opportunities through early identification of duplicate services across the ground process phases. The station set complexity is computed by simply summing all of the service complexities allocated to a station set then dividing it by the number of services required at the station set. This result is called the station set complexity factor, $\mathrm{SSCF}_{\mathrm{p}}$, and defined in Eq. (2).

$$
S S C F_{p}=\frac{1}{s} \sum_{j=1}^{S} S A C F_{j}
$$

where

$$
\begin{aligned}
& \mathrm{S}=\text { the total number of services allocated to station set } \\
& p=\text { station set index } \\
& j=\text { services index }
\end{aligned}
$$

Finally, ACI is computed simply by summing the station set complexity factors and dividing it by the total number of station sets. Eq. (3) defines the formula for computing ACI per string.

$$
A C I=\frac{1}{N} \sum_{i=1}^{N} S S C F_{i}
$$

where,

$$
\begin{aligned}
& \mathrm{N}=\text { the number of station set } \mathrm{s}(i \text { is the station set } \mathrm{s} \text { index) } \\
& \mathrm{SSCF}_{\mathrm{i}}=\text { the station set complexity factor }
\end{aligned}
$$

Eq. (4) assesses a complexity factor impact across all services. 


$$
C I_{k}=\frac{\sum_{j=1}^{S} W F_{k} \times A C F_{j}}{\sum_{j=1}^{S} W F_{k} \times M A X\left(A C F_{j}\right)}
$$

The ACI index ranges from 0 (high complexity) to 1 (low complexity). A result close to 1 represents efficient and simple ground system architectures. A result close to 0 represents complex ground system architectures. High ACI can be associated with express service station sets while low ACI can be associated with full service station sets. To compute ACI for entire spaceport having more than one string, sum the ACI's per string and divide by the total number of strings within the spaceport.

The ACI can be used to compare various spaceports for their complexities as well as assessing an impact of hosting a new operator within the spaceport. Also, station set complexity can be assessed by comparing the seven ACFs where a result close to 1 is simple to operate and sustain. To summarize, the ACI is used for assessing and comparing complexity at four levels: the service level; the station set level; the flight string level; and the spaceport level.

\section{Ground Systems Architecture Assessment Summary}

Two classes of flight configurations will be assessed to demonstrate the benefits of following the Ground Systems Architecture process of Figure 4. They are: the Notional Configuration-2 (NC-2) and Space Shuttle. ${ }^{25}$ (Note: There are two example configurations that were defined in McCleskey et al, but only Notional Configuration2 is assessed due to its uniqueness in architecture.) Figure 5 illustrates the two vehicle configurations. Vehicle NC-2 is a $3 / 3$ booster/orbiter engine split across a bimese vehicle pair with two over-wing drop tanks. The NASA Space Shuttle is $3 / 2$ Orbiter/SRB engine split with an external tandem tank arrangement $\left(\mathrm{LO}_{2}\right.$ forward tank \& $\mathrm{LH}_{2}$ aft tank). The assumptions for this assessment are:

- $\quad$ Assessment addresses only the Launch Definition Phase

- $\quad$ Assessment assumes only one launch station set

- $\quad$ Launch site for Space Shuttle vehicle is heritage KSC Pads 39A.

- $\quad$ Launch site for NC-2 is a redesigned, clean KSC Pad-39B.

- $\quad$ Launch definition phase begins after integrated vehicle arrives at the launch point

- Vehicles are transported via a mobile launch platform in the vertical orientation to the launch point

- $\quad$ Vehicles are vertically integrated off the launch point Specifically, for NC-2:

- Vehicle is launched within 24 hours of arrival at launch point, with propellant drain and roll-back occurring within two 8-hour work shifts

- $\quad$ Vehicle uses a mounting adapter with standard interfaces to the mobile launch platform

- Payload integration is performed off launch point

- Unplanned maintenance and repair is performed off launch point

Specifically, for Space Shuttle:

- Vehicle mounts to a custom mobile launch platform

- Payload integration performed on or off launch point

- Unplanned maintenance and repair is accommodated at launch point 

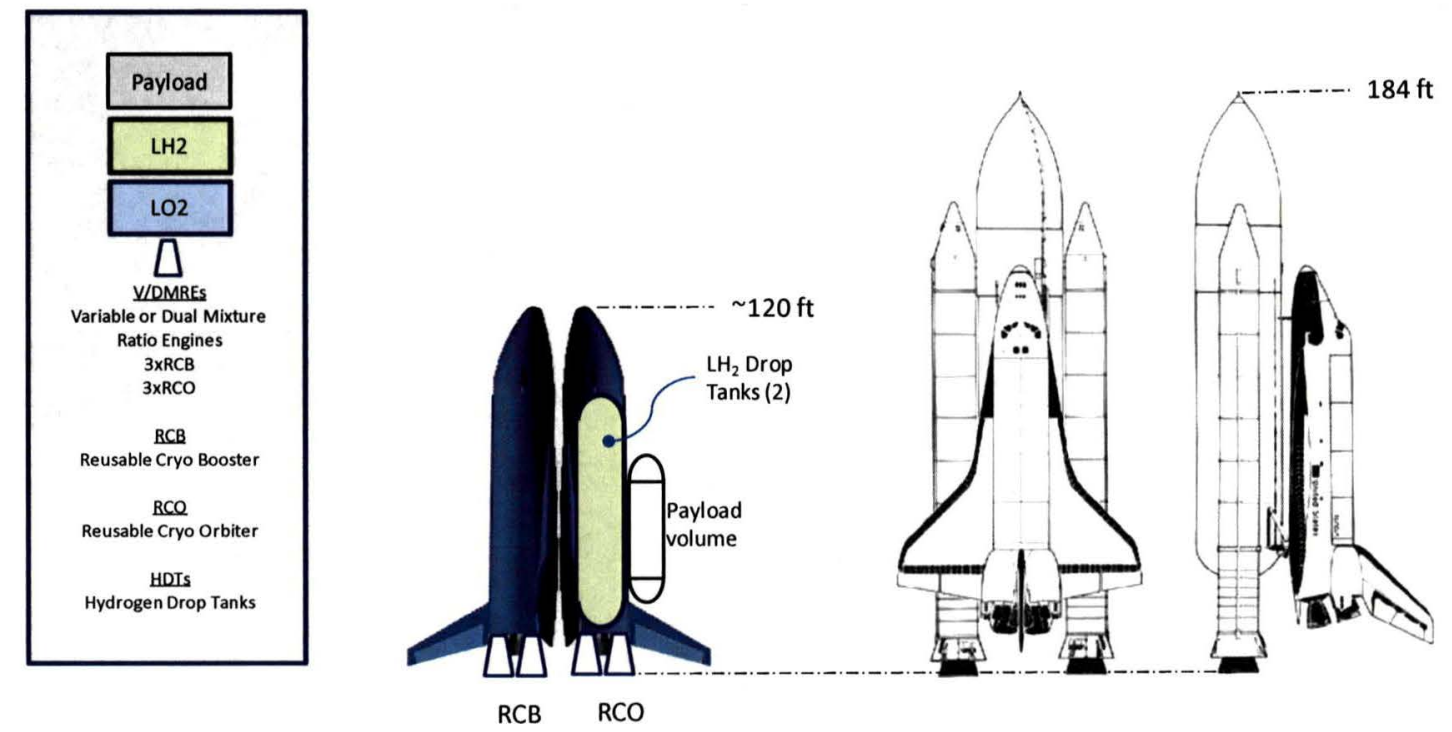

Figure 5-Two Vehicle Architectures: Notional Configuration-2 (left) and NASA Space Shuttle (right)

Attachment-D has the detailed worksheets for ACI calculations for the NC-2 vehicle and the Space Shuttle for the launch definition phase only. The ground services associated with each concept are in Table D1 of AttachmentD for NC-2 and in Table D2 for Space Shuttle. Each service is assessed against the seven ACFs. The ACF weighting factors, $W F_{k}$, were also assigned in the tables with their respective elevation and internal access factors. ${ }^{26,27}$ The tables use quantitative techniques in a qualitative process to gain insight into ground services at the architectural level. The resulting values are not absolute but should be viewed in a comparative context. The required groundsupplied services for the launch phase of NC-2 are far less complex than the Space Shuttle by a factor two in the ACI scale of 0 to 1 . The NC-2 vehicle, per Eq. (2), resulted in a launch station set ACI score of 0.8 , and the Space Shuttle was 0.4 . Per Eq. (4), the relative impacts of the complexity factors across the services are computed in the bottom row. The NC-2 architectural improvements are shown by comparing the numerical difference of the complexity impacts across the services between each concept. Figure 6 shows a NC-2 architecture that improves upon the seven ACFs.

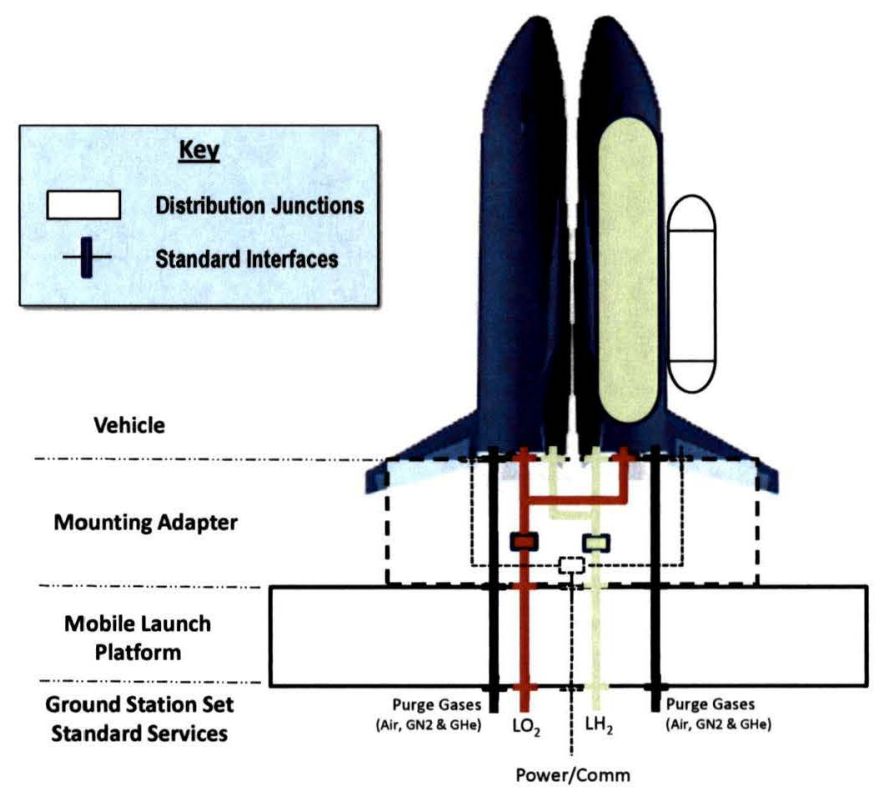

Figure 6-Notional Configuration 2 Common Interface Diagram

American Institute of Aeronautics and Astronautics 08012012 


\section{Commonality}

Commonality is the sharing of characteristics or configurations between and within entities for the purpose of improving economic, reliability, and logistic objectives. Commonality enables simpler, less complex architectures by eliminating uniqueness. What are the commonality and simplified approaches to minimize the impacts of ACFs? This is the fundamental challenge facing future space architects. This is needed to support the transformation of single use launch complexes to multi-use spaceports. ${ }^{28}$ Table-4 recommends design approaches for commonality that directly address each ACF. In support of these approaches, the following three commonality concepts were recommended to accommodate different vehicle architectures within the KSC multi-use spaceport: ${ }^{29}$

- To accommodate different types of vehicle mounts and to minimize MLP redesign impacts, use launch base adapters.

- Shelter flight-to-ground unique interfaces by adopting a standard structural tower appendage that is movable up and down the face of the tower.

- Use common hardware interfaces for fluid, gases and electrical connections.

The concept of incorporating adapters with standardized service interfaces is essential to achieving commonality. An adapter accommodates services from one standard to another to minimize the impacts of unique designs. In this instance, the adapter makes compatible the mounting of the flight vehicle with the ground. Also, unique interfaces can be adapted by standardizing on structural tower appendages and making their placement adjustable. In addition, the adapter in Figure 6 accommodates for the following standard services and interfaces: propellant supply; purge gas supply; electrical power; and command, control, and communication.

Table 4: Commonality Design Approaches (1 of 2)

\begin{tabular}{|c|c|c|}
\hline $\mathrm{ACF}_{i}$ and Design Objective & Commonality Approach & Benefit of Commonality \\
\hline $\begin{array}{l}\mathrm{ACF}_{1} \text { - Service Elevation } \\
\text { Minimize elevated ground services }\end{array}$ & $\begin{array}{l}\text { Standardize on umbilical locations } \\
\text { as function of vehicle element, e.g., } \\
1 \text { st stage and } 2^{\text {nd }} \text { stage. All vehicles } \\
\text { have a } 1 \text { st stage. A standardized } \\
\text { approach would be all } 1^{\text {st }} \text { stage } \\
\text { elements to have tail servicing. }\end{array}$ & $\begin{array}{l}\text { - This would reduce the need for elevated } \\
\text { services and reduce complexity of the service. }\end{array}$ \\
\hline $\begin{array}{l}\mathrm{ACF}_{2}-\text { External Access } \\
\text { Ease of providing routine external } \\
\text { services }\end{array}$ & $\begin{array}{l}\text { Standardize on GS to FS interfaces } \\
\text { at the vehicle outer mold-line. }\end{array}$ & $\begin{array}{l}\text { - Reduces number of unique locations requiring } \\
\text { access. } \\
\text { - Reduces the number of unique components at } \\
\text { key interfaces. } \\
\text { - Reduces amount of resources required to } \\
\text { qualify the component and provide service. } \\
\text { - Standard sizes promote universal servicing, } \\
\text { e.g., on orbit servicing. }\end{array}$ \\
\hline $\begin{array}{l}\mathrm{ACF}_{3} \text { - Internal Access } \\
\text { Control the number and volume of } \\
\text { closed compartments and interstitial } \\
\text { spaces in the vehicle design } \\
\text { (exclusive of crew cabin) to } \\
\text { minimize the number of internal } \\
\text { accesses as a function of ground } \\
\text { processing life cycle. }\end{array}$ & $\begin{array}{l}\text { Focus on providing common flight } \\
\text { line level of maintenance to } \\
\text { eliminate intrusive vehicle } \\
\text { operations in the design. } \\
\text { Specifically, avoid compartments } \\
\text { requiring safety purges and routine, } \\
\text { internal ground crew access for the } \\
\text { following potential interstitial } \\
\text { volumes: } \\
\text { 1. Inter-tanks } \\
\text { 2. Inter-stages } \\
\text { 3. Closed propulsion area } \\
\text { 4. Payload area }\end{array}$ & $\begin{array}{l}\text { Improves retention of functional integrity } \\
\text { through the elimination of routine panel } \\
\text { removals, fluid and electrical disconnections, } \\
\text { access kit installation and removal, and } \\
\text { compartment closeout, and functional retest. } \\
\text { - Decrease ground processing cycle time. } \\
\text { - Eliminates or reduces GS servicing }\end{array}$ \\
\hline
\end{tabular}


Table 4: Commonality Design Approaches (2 of 2)

\begin{tabular}{|c|c|c|}
\hline $\mathrm{ACF}_{i}$ and Design Objective & Commonality Approach & Benefit of Commonality \\
\hline $\begin{array}{l}\mathrm{ACF}_{4}-\text { Hazard Types } \\
\text { Minimize large quantity solids, toxic } \\
\text { propellants, ordnance/pyrotechnics, } \\
\text { suspended loads }\end{array}$ & $\begin{array}{l}\text { Focus on eliminating toxic } \\
\text { propellants. } \\
\text { Reduce the number of required } \\
\text { ordnance/pyrotechnics devices. } \\
\text { Use standard vehicle element } \\
\text { attachment methods for integration } \\
\text { enabled through automated vehicle } \\
\text { element handling operations. } \\
\text { Consider methods compatible with } \\
\text { use of rails, robotic handling, etc. }\end{array}$ & $\begin{array}{l}\text { - Reduces the number of supporting GS service } \\
\text { hazards during Launch Phase and I\&C phase. } \\
\text { - Reduces complexity on FS and GS. } \\
\text { - Opportunity to synergistically reduce the } \\
\text { number of propellants via using a common } \\
\text { fuel for all propulsion systems. } \\
\text { - Potentially reduces the number of umbilical } \\
\text { connections and service locations. } \\
\text { - Reduces time and effort for alignment and } \\
\text { registration of vehicle elements during } \\
\text { integration. } \\
\text { - Automated vehicle assembly and integration } \\
\text { operations. }\end{array}$ \\
\hline $\begin{array}{l}\mathrm{ACF}_{5}-\mathrm{Command} \text { and Control } \\
\text { Create a standard command and } \\
\text { control interface that allows } \\
\text { simplified and reduced operations }\end{array}$ & $\begin{array}{l}\text { Standardize command \& control } \\
\text { communications protocols and } \\
\text { physical interfaces. } \\
\text { Standardize policies and design } \\
\text { practices that retain functional } \\
\text { integrity upon receipt of an element } \\
\text { (from the factory or return from } \\
\text { space). } \\
\text { Standardize on automated functions } \\
\text { that simplify ground operations, and } \\
\text { promote diagnostic/prognostic } \\
\text { capabilities. }\end{array}$ & $\begin{array}{l}\text { - Standardizing on C\&C protocol improves } \\
\text { interoperability for a multi-use spaceport. } \\
\text { - Reduces the number of unique GS to FS } \\
\text { electrical interfaces. } \\
\text { - Reduces the number of unique C\&C station } \\
\text { sets. } \\
\text { - Reduces errors in ground operations and } \\
\text { increases throughput. }\end{array}$ \\
\hline $\begin{array}{l}\mathrm{ACF}_{6}-\mathrm{Required} \text { Maintenance Level } \\
\text { Design for flight line level of } \\
\text { maintenance and avoid routine } \\
\text { requirements for depot-like } \\
\text { maintenance. }\end{array}$ & $\begin{array}{l}\text { Promote industry consensus } \\
\text { standards based on military and } \\
\text { commercial aircraft maintenance } \\
\text { doctrine and standards. } \\
\text { Design to common ground services. }\end{array}$ & $\begin{array}{l}\text { - Reduces or eliminates requirement for ground } \\
\text { supplied services and infrastructure to support } \\
\text { depot-like operations for routine space flights } \\
\text { - Improves ground processing responsiveness } \\
\text { - Improves confidence in certifications for } \\
\text { flight by reducing variance in operations and } \\
\text { unplanned actions. }\end{array}$ \\
\hline $\begin{array}{l}\mathrm{ACF}_{7}-\text { Capability Level } \\
\text { Design capabilities that allow for } \\
\text { extensibility and growth margin. }\end{array}$ & $\begin{array}{l}\text { Design for modularity, portability, } \\
\text { adaptability, and reusability through } \\
\text { partitioning of design functions. } \\
\text { Standardize on physical interfaces to } \\
\text { accommodate technology } \\
\text { transparency. } \\
\text { Establish an industry standard for } \\
\text { common ground services. }\end{array}$ & $\begin{array}{l}\text { - Accommodates multi-use operation } \\
\text { - Allows use in different locations. } \\
\text { - Allows seamless upgrade of architectural } \\
\text { capability. } \\
\text { - Reduces re-certification time and expense } \\
\text { - Reduces number of unique test facilities and } \\
\text { dedicated infrastructure. }\end{array}$ \\
\hline
\end{tabular}




\section{Conclusion}

A structured system engineering process was developed by the authors (see Figure 4). This process assesses flight-to-ground service compatibility. An architecture complexity index, ACI, was developed. The ACI assesses the complexity of ground services required to support a given flight system architecture. The ACI can then be used as a standard measure for comparing different space transportation architectures.

Pursuing the design approaches identified in Table 4 early in the architecture design process, for both flight and ground systems will enable the successful development of multi-use spaceports, and ultimately improve the life cycle affordability and productivity.

Following the process in Figure 4, and comparing the ACIs and ACFs results, the flight systems burdens on the ground systems are made visible early in the design phase. It identifies the operational complexities and unique services throughout the ground system lifecycle. These burdens translate into opportunities for improving affordability through commonality. This was demonstrated in the examples chosen for this paper.

Following the process in Figure 4 and computing the ACI, demonstrated that the NC-2 vehicle architecture had effectively accounted for the ACFs during its formulation, resulting in far simpler operations. Addressing the seven ACFs as a design priority will improve the architectural affordability through commonality concepts of Table 4 . Following this conceptual design process from the beginning will make the flight and ground systems compatible and will result in an affordable architecture that satisfies the desired mid- and long-term goals (see Table-2).

\section{Acknowledgements}

The authors wish to acknowledge the many hours invested by the Space Propulsion Synergy Team professionals who have volunteered their time, treasure, and talent over the many years of its existence. Without their many useful products, this paper could not have been undertaken. Jerry Garcia, the lead author, would also like to thank the staff of the Engineering and Technology Directorate of the Kennedy Space Center, and in particular, Mr. Hector Delgado, for technical and editing guidance, as well as his experience and substantive contributions in the subject. 


\section{Attachment-A}

Figure-A1: Process for Defining a Ground Systems Architecture (Detail View)

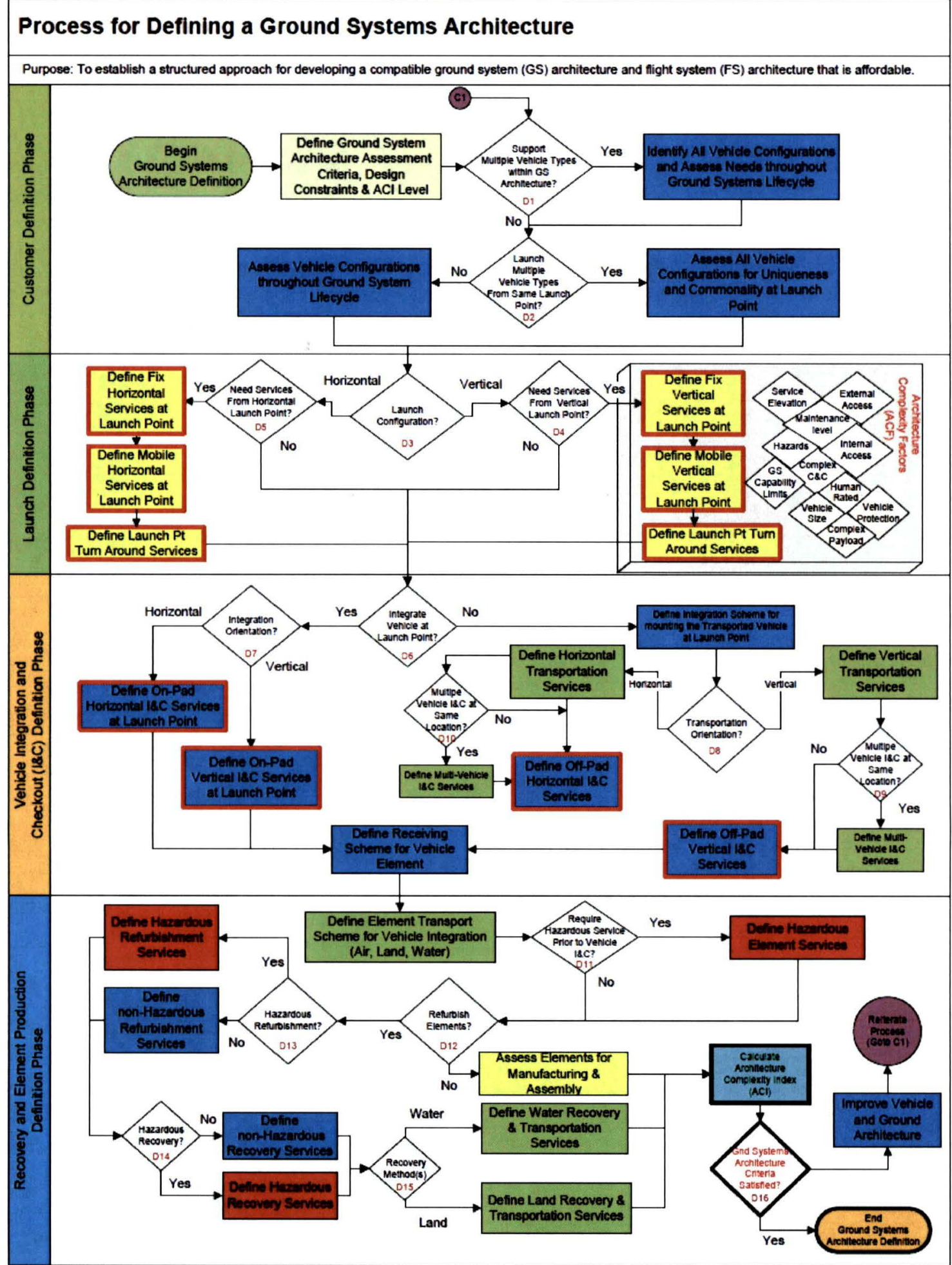

American Institute of Aeronautics and Astronautics 08012012 


\section{Attachment-B}

Table B1-Key Architectural Drivers and Potential GS Architectural Concerns (1 of 3)

\begin{tabular}{|c|c|c|}
\hline $\begin{array}{l}\text { Phase } \\
\end{array}$ & Architectural Driver & Potential GS Architectural Concerns \\
\hline $\begin{array}{l}\text { Customer Definition Phase } \\
\text { The purpose of this phase is to } \\
\text { define the vehicle types and } \\
\text { launch point locations within the } \\
\text { Spaceport. }\end{array}$ & $\begin{array}{l}\text { D1- Supporting Multiple Vehicle Types } \\
\text { from the same GS Architecture. } \\
\text { D2 - Launch Multiple Vehicle Types } \\
\text { from Same Launch Point }\end{array}$ & $\begin{array}{l}\text { - Ensuring that sufficient real estate and infrastructure is available for all vehicle operators. } \\
\text { - Trade-off between using existing vs. building new spaceport infrastructure and services. } \\
\text { - Minimize environmental impacts due to increase of hazards at spaceport. } \\
\text { - } \text { occurring in closer proxes (Explosions Zones) impacts due to more concurrent hazardous operations } \\
\text { - Number and types of hazards services required by all vehicles. } \\
\text { - Supporting different type of human rated vehicles and their unique safety requirements. } \\
\text { - Ensuring sufficient spaceport capability to service all current and future vehicle operators. } \\
\text { - Management of flight rates due to the increases in the number of launches within the spaceport. } \\
\text { - Efficient management of share services with the spaceport. } \\
\text { - Sstablishing a compatible spaceport business model for all vehicle operators. } \\
\text { - Support for different classes of vehicles (size and complexity of outer mold line, OML) from same launch } \\
\text { - Number and complexity of unique services required to support all vehicle types, i.e., lack of common services } \\
\text { between vehicles. } \\
\text { - Number of unique interfaces required to support all vehicle types, i.e., lack of standardize interface between } \\
\text { vehicles. } \\
\text { - GS needs to have sufficient capability to service all vehicle types from same launch point. }\end{array}$ \\
\hline $\begin{array}{l}\text { Launch Definition Phase } \\
\text { The purpose of this phase is to } \\
\text { define the vehicle launch } \\
\text { configuration and its services at } \\
\text { the launch point. }\end{array}$ & $\begin{array}{l}\text { D3 - Launch Configuration } \\
\text { D4 - Vertical (Fixed/Mobile) Services } \\
\text { required at Launch point } \\
\text { D5 - Horizontal (Fixed/Mobile) Services } \\
\text { required at Launch point }\end{array}$ & $\begin{array}{l}\text { - Vehicle duration at launch point. } \\
\text { - Number and complexity of services required at launch point. } \\
\text { - Services require for emergency egress including abort contingencies. } \\
\text { - The amount of vehicle protection at launch point due to environments (natural and/or induced). } \\
\text { - The number of vehicle accesses required at the launch point. } \\
\text { - For a human raced vehicle, required size of flight and ground crew } \\
\text { - Requirements for late access to payload/crew/vehicle. } \\
\text { - Large vehicles may impact scale of launch facility infrastructure and required geographical footprint of launch } \\
\text { point. } \\
\text { - Number of services above ground level increases operational complexity. } \\
\text { - Need to access beyond OML (internal access to closed compartments) increases operational complexity. } \\
\text { - Payload access required at launch point. } \\
\text { - Tradeoff between fixed GS services versus mobile GS services at launch point. }\end{array}$ \\
\hline
\end{tabular}

American Institute of Aeronautics and Astronautics 08012012 
Table B1-Key Architectural Drivers and GS Architectural Concerns (2 of 3)

\begin{tabular}{|c|c|c|}
\hline $\begin{array}{r}\text { Phase } \\
\end{array}$ & Architectural Driver & GS Architectural Concerns \\
\hline $\begin{array}{l}\text { Vehicle Integration and } \\
\text { Checkout (I\&C) Definition } \\
\text { Phase } \\
\text { The purpose of this phase is } \\
\text { to define the I\&C services } \\
\text { and vehicle transportation } \\
\text { services up to the launch } \\
\text { point mount. } \\
\text { Note: An element is a } \\
\text { component of the overall } \\
\text { launch vehicle stack. It } \\
\text { includes all stages, the } \\
\text { boosters, the spacecraft, and } \\
\text { the payload. }\end{array}$ & $\begin{array}{l}\text { D7 - At Launch Point Integration } \\
\text { Orientation } \\
\text { D8 - Transportation Orientation to } \\
\text { Launch Point }\end{array}$ & 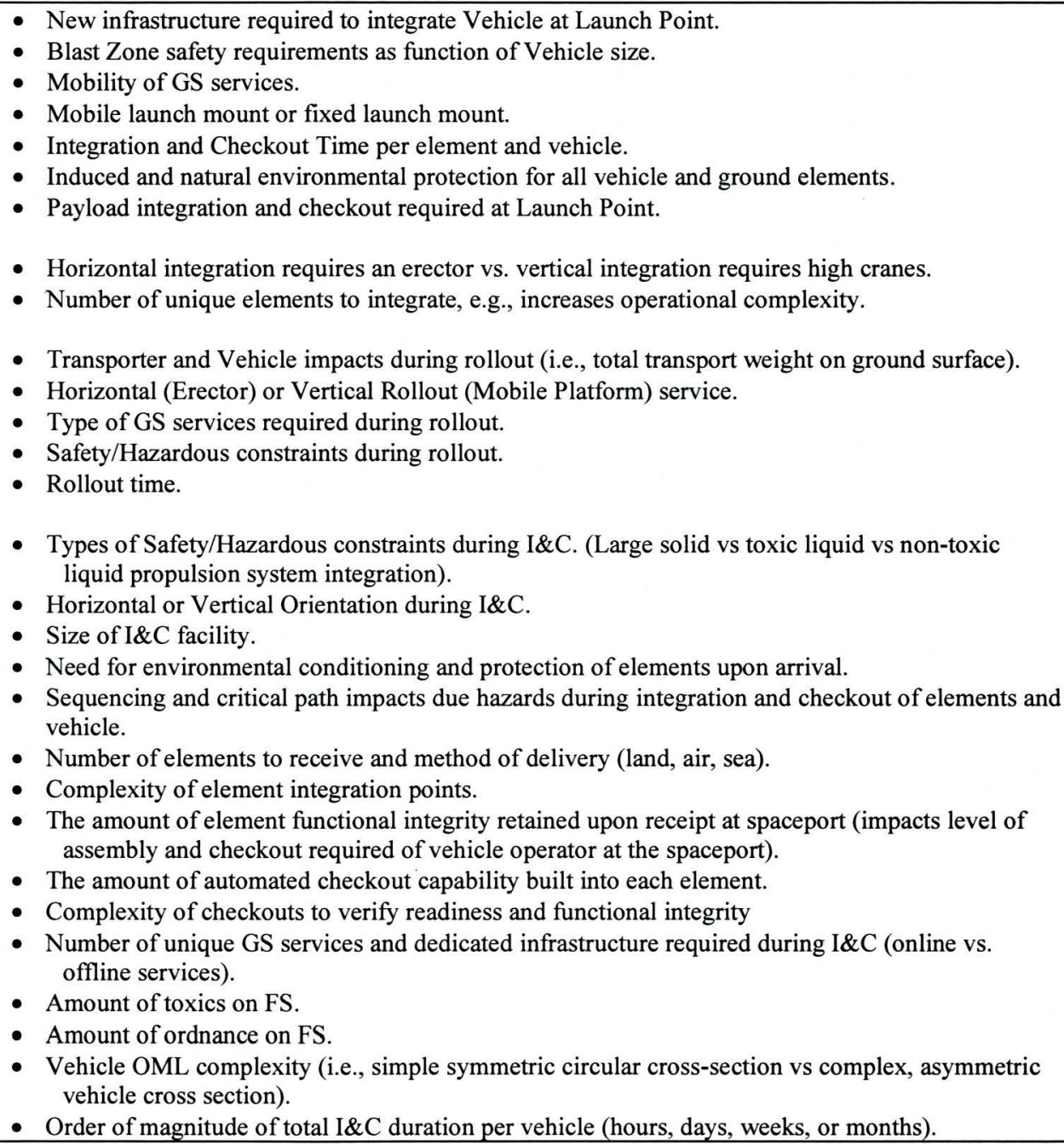 \\
\hline
\end{tabular}


Table B1-Key Architectural Drivers and GS Architectural Concerns (3 of 3)

\begin{tabular}{|c|c|c|}
\hline Phase & Architectural Driver & GS Architectural Concerns \\
\hline $\begin{array}{l}\text { Recovery and Element } \\
\text { Production Definition Phase }\end{array}$ & $\begin{array}{l}\text { D11 - Require Hazardous Servicing } \\
\text { prior to I\&C. }\end{array}$ & - Type of toxic services, complexity of service and service location \\
\hline \multirow[t]{4}{*}{$\begin{array}{l}\text { The purpose of this phase is } \\
\text { to define the manufacturing } \\
\text { services for each element. }\end{array}$} & D12 - Need to Refurbish Elements & $\begin{array}{l}\text { - Number of elements to refurbish. } \\
\text { - Degree of refurbishment (exterior refurbishment, or depot-level teardown and remanufacturing) } \\
\text { - Frequency of refurbishment. }\end{array}$ \\
\hline & D13 - Hazardous Refurbishment & $\begin{array}{l}\text { - Safety/hazardous constraints on refurbishment. } \\
\text { - Level of safing and de-servicing of unspent ordnance and toxic commodities. } \\
\text { - Complexity of refurbishment and verification. }\end{array}$ \\
\hline & D14 - Hazardous Recovery & $\begin{array}{l}\text { - Hazard type(s). } \\
\text { - Safety/hazardous constraints on recovery. } \\
\text { - Complexity of recovery at landing site. }\end{array}$ \\
\hline & $\begin{array}{l}\text { D15 -Recovery Method (Land or } \\
\text { Water) }\end{array}$ & $\begin{array}{l}\text { - Size of element to recovery. } \\
\text { - Location of recovery site. } \\
\text { - Response time to recover element. } \\
\text { - Duration of recovery and transport time (hours, days, weeks). } \\
\text { - Transportation method for recovered element. } \\
\text { - Transportation method for recovered element to manufacture site. } \\
\text { - Complexity of GS services and dedicated infrastructure to support recovered element. }\end{array}$ \\
\hline
\end{tabular}




\section{Attachment-C}

Table C1-Ground Systems Architecture Complexity Factors (ACFs) with Assessment Criteria (Note: "Highest value" is least impact due to complexity; "lowest value" is greatest impact)

\begin{tabular}{|c|c|c|c|c|c|c|}
\hline $\begin{array}{c}\text { Service } \\
\text { Elevation }\end{array}$ & $\begin{array}{c}\text { External } \\
\text { Access } \\
\text { (Outer Mold } \\
\text { line) }\end{array}$ & $\begin{array}{c}\text { Internal } \\
\text { Access } \\
\text { (Personnel } \\
\text { Compartment } \\
\text { Entry) }\end{array}$ & $\begin{array}{l}\text { Hazard Type } \\
(\text { See Table-3a) }\end{array}$ & $\begin{array}{l}\text { Command \& } \\
\text { Control } \\
(\text { See Table-3b) }\end{array}$ & $\begin{array}{c}\text { Required } \\
\text { Maintenance } \\
\text { Level }\end{array}$ & $\begin{array}{c}\text { Capabilities } \\
\text { Level }\end{array}$ \\
\hline $\mathrm{ACF}_{1}$ & $\mathbf{A C F}_{2}$ & $\mathrm{ACF}_{\mathbf{3}}$ & $\mathrm{ACF}_{4}$ & $\mathrm{ACF}_{5}$ & $\mathrm{ACF}_{6}$ & $\mathrm{ACF}_{7}$ \\
\hline $\begin{array}{l}\text { round Level } \\
\text { Access } \\
\text { is best }\end{array}$ & $\begin{array}{l}\text { Simple mold } \\
\text { line access } \\
\text { is best }\end{array}$ & $\begin{array}{c}\text { No Internal Access } \\
\text { is best }\end{array}$ & $\begin{array}{l}\text { Type-IV } \\
\text { is best }\end{array}$ & $\begin{array}{l}\text { Class-IV } \\
\text { is best }\end{array}$ & $\begin{array}{c}\text { Flight Line Level is } \\
\text { best }\end{array}$ & $\begin{array}{c}\text { Ample Margin is } \\
\text { best }\end{array}$ \\
\hline $\mathrm{WF}_{1}$ & $\mathrm{WF}_{2}$ & $\mathrm{WF}_{3}$ & $\mathrm{WF}_{4}$ & $\mathrm{WF}_{5}$ & $\mathrm{WF}_{6}$ & $\mathrm{WF}_{7}$ \\
\hline $\begin{array}{l}10-\text { All } \\
\text { services } \\
\text { provided at } \\
\text { Zero Level }\end{array}$ & $\begin{array}{l}10-\text { Only } \\
\text { Zero Level } \\
\text { Access }\end{array}$ & $\begin{array}{l}10-\text { No Internal } \\
\text { Access }\end{array}$ & 10 - Type-IV & 10 - Class-IV & $\begin{array}{l}10 \text { - All Flight } \\
\text { Line Level } \\
\text { Maintenance }\end{array}$ & $\begin{array}{l}10-\text { Ample } \\
\text { Margin, Very } \\
\text { Extensible }\end{array}$ \\
\hline \multirow[t]{2}{*}{ to } & \multirow[t]{2}{*}{ to } & \multirow[t]{2}{*}{ to } & 6 - Type III & 6 - Class III & $\begin{array}{l}\text { 6-Mostly } \\
\text { Intermediate } \\
\text { Level } \\
\text { Maintenance }\end{array}$ & $\begin{array}{l}\text { 6- Moderate } \\
\text { Margin, } \\
\text { Somewhat } \\
\text { Extensible }\end{array}$ \\
\hline & & & 3-Type II & 3 -Class II & $\begin{array}{l}3 \text { - Some Depot } \\
\text { Level } \\
\text { Maintenance }\end{array}$ & $\begin{array}{l}3-\text { No } \\
\text { Margin, Not } \\
\text { Extensible } \\
\end{array}$ \\
\hline $\begin{array}{l}1 \text { - Services } \\
\text { provided at } \\
\text { all Elevations } \\
\text { of Vehicle } \\
\text { height }\end{array}$ & $\begin{array}{l}1- \\
\text { Requires } \\
\text { Access } \\
\text { to entire } \\
\text { Vehicle } \\
\text { each flight }\end{array}$ & $\begin{array}{l}1 \text { - Requires } \\
\text { Internal Access } \\
\text { to all } \\
\text { compartments } \\
\text { each flight }\end{array}$ & 1 - Type I & 1 -Class I & $\begin{array}{l}1 \text { - All Depot } \\
\text { Level } \\
\text { Maintenance }\end{array}$ & $\begin{array}{l}1-\text { Negative } \\
\text { Margin, Not } \\
\text { Extensible }\end{array}$ \\
\hline
\end{tabular}

Table C2 - Hazards Type Table

(Note: "Highest value" is least impact due to hazard; "lowest value" is greatest impact)

\begin{tabular}{|c|c|}
\hline Type & Hazard Type $^{12}$ \\
\hline $\begin{array}{l}\text { Higher Type } \\
\text { is best }\end{array}$ & $\begin{array}{c}\text { No Hazards } \\
\text { is best }\end{array}$ \\
\hline 10 - Type-IV & - $\quad$ No Hazards \\
\hline 6 - Type III & $\begin{array}{ll}\text { - } & \text { Falling objects } \\
\text { - } & \text { Interferences, moving/colliding surfaces } \\
\text { - } & \text { Combustion, Fire } \\
\text { - } & \text { Cryogenic Frost bite } \\
\text { - } & \text { Asphyxiation (inert Gases) } \\
\text { - } & \text { High Pressure Fluid } \\
\text { - } & \text { Hi-Power Electrical (electrocution) } \\
\end{array}$ \\
\hline 3 - Type II & $\begin{array}{ll}- & \text { Radiation } \\
- & \text { Bio Hazards } \\
\text { - } & \text { Suspended load } \\
\text { - } & \text { Ordnance, pyrotechnic } \\
\end{array}$ \\
\hline 1 - Type I & $\begin{array}{ll}- & \text { Toxic Fluid Hazard (hypergolic) } \\
\text { - } & \text { Large quantity of solid propellants (quantity } \\
\text { distance, or QD) }\end{array}$ \\
\hline
\end{tabular}


Table C3 - Command \& Control Class Table

(Note: "Highest value" is least impact due to C\&C, "lowest value" is greatest impact)

\begin{tabular}{|l|l|l|l|l|}
\hline Characteristics \Level & $10-$ Class-IV & 6 - Class III & 3 - Class II & $1-$ Class I \\
\hline $\begin{array}{l}\text { Number of Control \& } \\
\text { Monitoring Points }\end{array}$ & \multicolumn{1}{|c|}{$<00$} & \multicolumn{1}{|c|}{$<00$} & $>600$ \\
\hline Control Location(s) & Service Panel & $\begin{array}{l}\text { Dedicate Station Set } \\
\text { and no Dedicated } \\
\text { Control Room }\end{array}$ & $\begin{array}{l}\text { Dedicate Station } \\
\text { Set and Dedicated } \\
\text { Control Room }\end{array}$ & $\begin{array}{l}\text { Distributed across } \\
\text { dedicated Station } \\
\text { Sets and multiple } \\
\text { Control Rooms }\end{array}$ \\
\hline Physical Interface & $\begin{array}{l}\text { Completely } \\
\text { Wireless } \\
\text { Interface }\end{array}$ & $\begin{array}{l}\text { Optical Interface } \\
\text { and Hardwire } \\
\text { Power Interface }\end{array}$ & Multiple Cables & $\begin{array}{l}\text { Cable per Signal } \\
\text { Interface }\end{array}$ \\
\hline $\begin{array}{l}\text { Functional Integrity } \\
\text { Monitoring }\end{array}$ & $\begin{array}{l}\text { All systems have } \\
\text { Integrated into } \\
\text { Protocol and I/F } \\
\text { Hardware. }\end{array}$ & $\begin{array}{l}\text { For selected } \\
\text { systems, Integrated } \\
\text { into I/F Hardware }\end{array}$ & $\begin{array}{l}\text { Performs Limit } \\
\text { Monitoring on } \\
\text { critical control } \\
\text { points }\end{array}$ & No monitoring \\
\hline Control Method & All Automated & $\begin{array}{l}\text { Mostly Automated } \\
\text { to Some Supervised }\end{array}$ & $\begin{array}{l}\text { Mostly Supervised } \\
\text { to Some Manual }\end{array}$ & All Manual \\
\hline Supports Launch Count & Completely No & $\begin{array}{l}\text { More No's than } \\
\text { Yes's }\end{array}$ & $\begin{array}{l}\text { More Yes's than } \\
\text { No's }\end{array}$ & Completely Yes \\
\hline $\begin{array}{l}\text { System Criticality Level } \\
\text { Classification }\end{array}$ & Criticality-3 & Mostly Criticality-2 & $\begin{array}{l}\text { Some Criticality- } \\
\text { 1R }\end{array}$ & Criticality-1 \& 1R \\
\hline
\end{tabular}




\section{Attachment-D}

Table D1-Ground Systems Launch Definition Phase Assessment (Notional Configuration 2)

\begin{tabular}{|c|c|c|c|c|c|c|c|c|c|c|}
\hline Phase & $\begin{array}{l}\text { Architectural } \\
\text { Driver }\end{array}$ & Services Required $^{6}$ & $\mathbf{A C F}_{1}$ & $\mathbf{A C F}_{2}$ & $\mathbf{A C F}_{3}$ & $\mathbf{A C F}_{4}$ & $\mathbf{A C F}_{5}$ & $\mathrm{ACF}_{6}{ }^{7}$ & $\mathbf{A C F}_{7}$ & \multirow[t]{2}{*}{ SACF } \\
\hline \multirow{13}{*}{$\begin{array}{l}\text { Launch } \\
\text { Definition } \\
\text { Phase }\end{array}$} & \multicolumn{2}{|r|}{ Launch Definition Phase Weightings, $\mathrm{WF}_{\mathrm{k}}$ (\% contribution) } & $28 \%$ & $14 \%$ & $18 \%$ & $16 \%$ & $10 \%$ & $7 \%$ & $7 \%$ & \\
\hline & $\begin{array}{l}\text { D3 - Launch } \\
\text { Configuration }\end{array}$ & $\begin{array}{l}\text { Orientation: Vertical } \\
\text { D3.1 Need vertical mounting services: } \\
\text { - Uses Mobile Launch Platform with standard launch } \\
\text { mount adapter } \\
\text { - No vehicle stabilizers required }\end{array}$ & $\geq 9$ & $\geq 9$ & $\mathrm{n} / \mathrm{a}$ & $\mathrm{n} / \mathrm{a}$ & $\mathrm{n} / \mathrm{a}$ & $\geq 8$ & $\geq 7$ & 0.9 \\
\hline & & $\begin{array}{l}\text { D4.1 Need single } \mathrm{LH}_{2} / \mathrm{LO}_{2} \text { Propellant Loading service } \\
\text { connection at Aft (accessible from Zero Level); no elevated } \\
\text { vent services }\end{array}$ & $\geq 9$ & $\geq 9$ & 10 & 6 & $\geq 6$ & $\geq 8$ & $\geq 7$ & 0.8 \\
\hline & & $\begin{array}{l}\text { D4.2 Need single Environment Controls System (ECS) at } \\
\text { common service }\left(\text { air/GN }{ }_{2} \text { ) connection point at element's Aft }\right. \\
\text { (vehicle supplies P/L ECS) }\end{array}$ & $\geq 9$ & $\geq 9$ & 10 & 6 & $\geq 6$ & $\geq 8$ & $\geq 9$ & 0.8 \\
\hline & & $\begin{array}{l}\text { D4.3 Need single GHe at common service connection point at } \\
\text { Aft }\end{array}$ & $\geq 9$ & $\geq 9$ & 10 & 6 & $\geq 6$ & $\geq 8$ & $\geq 7$ & 0.8 \\
\hline & & $\begin{array}{l}\text { D4.4 Need single } \mathrm{GN}_{2} \text { at common service connection point at } \\
\text { Aft }\end{array}$ & $\geq 9$ & $\geq 9$ & 10 & 6 & $\geq 6$ & $\geq 8$ & $\geq 7$ & 0.8 \\
\hline & D4 - Vertical Services & $\begin{array}{l}\text { D4.5 Need single Power at common service connection point } \\
\text { at Aft (vehicle supplies P/L Power) }\end{array}$ & $\geq 9$ & $\geq 9$ & 10 & $\geq 7$ & $\geq 6$ & $\geq 8$ & $\geq 8$ & 0.8 \\
\hline & $\begin{array}{l}\text { required at Launch } \\
\text { point }\end{array}$ & $\begin{array}{l}\text { D4.6 Need single T-0 Communication connection w/ std. } \\
\text { protocol to KSC LCC (Hardwire) at common service } \\
\text { connection point at Aft (P/L Communicates thru vehicle } \\
\text { comm. system, and not thru dedicated ground hardwire) }\end{array}$ & $\geq 9$ & $\geq 9$ & 10 & $\mathrm{n} / \mathrm{a}$ & $\geq 6$ & $\geq 8$ & $\geq 9$ & 0.9 \\
\hline & & $\begin{array}{l}\text { D4.7 Need RF comm. (vehicle and P/L RF); antenna hats } \\
\text { removed at assembly/integration point prior to rollout }\end{array}$ & 10 & 10 & $\mathrm{n} / \mathrm{a}$ & 3 & $\geq 6$ & $\mathrm{n} / \mathrm{a}$ & $\geq 9$ & 0.8 \\
\hline & & $\begin{array}{l}\text { D4.8 Need remote ordnance arming service; installation at } \\
\text { assembly/integration point }\end{array}$ & $\mathrm{n} / \mathrm{a}$ & $\mathrm{n} / \mathrm{a}$ & $\mathrm{n} / \mathrm{a}$ & $\mathrm{n} / \mathrm{a}$ & $\geq 6$ & $\mathrm{n} / \mathrm{a}$ & $\geq 9$ & 0.7 \\
\hline & & $\begin{array}{l}\text { D4.9 Need "express" services at launch point (launch within } \\
24 \text { hours of vehicle arrival at launch point; drain and roll-back } \\
\text { vehicle to assembly point < two } 8 \text { hour shifts) }\end{array}$ & $\mathrm{n} / \mathrm{a}$ & $\mathrm{n} / \mathrm{a}$ & $\mathrm{n} / \mathrm{a}$ & $\mathrm{n} / \mathrm{a}$ & $\geq 6$ & $\geq 8$ & $\geq 8$ & 0.7 \\
\hline & & Complexity impacts across all services, $\mathbf{C I}_{\mathbf{k}}=$ & 0.9 & 0.9 & 1.0 & 0.6 & 0.8 & 0.8 & 0.8 & $\mathrm{SSCF}=0.8$ \\
\hline & $\begin{array}{l}\text { D5 - Horizontal } \\
\text { Services required }\end{array}$ & & & & & & & & & \\
\hline
\end{tabular}

${ }^{6}$ Each service identified is independently supplied to each element, Booster and Orbiter, but share a common interface design.

${ }^{7}$ Maintenance level applies only to ground equipment at launch point for this assessment. Vehicle maintenance level is not applicable for Launch Definition Phase 
Table D2-Ground Systems Launch Definition Phase Assessment (Space Shuttle)

\begin{tabular}{|c|c|c|c|c|c|c|c|c|c|c|}
\hline Phase & $\begin{array}{c}\text { Architectural } \\
\text { Driver }\end{array}$ & Services Required $^{8}$ & $\mathbf{A C F}_{1}$ & $\mathbf{A C F}_{2}$ & $\mathrm{ACF}_{3}$ & $\mathbf{A C F}_{4}$ & $\mathbf{A C F}_{5}$ & $\mathrm{ACF}_{6}{ }^{9}$ & $\mathbf{A C F}_{7}$ & SACF \\
\hline \multirow{15}{*}{$\begin{array}{l}\text { Launch } \\
\text { Definition } \\
\text { Phase }\end{array}$} & & Launch Definition Phase Weightings, $\mathrm{WF}_{\mathrm{k}}$ (\% contribution) & $28 \%$ & $14 \%$ & $18 \%$ & $16 \%$ & $10 \%$ & $7 \%$ & $7 \%$ & \\
\hline & $\begin{array}{l}\text { D3 - Launch } \\
\text { Configuration }\end{array}$ & $\begin{array}{l}\text { Orientation: Vertical } \\
\text { D3.1 Need vertical mounting services: } \\
\text { - Uses custom-dedicated Mobile Launch Platform. } \\
\text { - Elevated connections to pad structures (RSS/FSS connections } \\
\text { to vehicle). } \\
\text { - No vehicle stabilizers required. }\end{array}$ & $\geq 6$ & $\leq 5$ & $\mathrm{n} / \mathrm{a}$ & 6 & $\mathrm{n} / \mathrm{a}$ & $\leq 5$ & $\leq 4$ & 0.6 \\
\hline & \multirow{12}{*}{$\begin{array}{l}\text { D4 - Vertical } \\
\text { Services required at } \\
\text { Launch point }\end{array}$} & $\begin{array}{l}\text { D4.1a - Need single } \mathrm{LH}_{2} / \mathrm{LO}_{2} \text { Propellant Loading service } \\
\text { connection at Aft (accessible from Zero Level); requires separate } \\
\text { elevated } \mathrm{LO}_{2} \text { and } \mathrm{LH}_{2} \text { vent services and internally accessed } \\
\text { compartments (Orb aft and ET intertank) at different levels. }\end{array}$ & $\leq 7$ & $\leq 7$ & $\leq 3$ & 6 & $\leq 3$ & $\leq 5$ & $\leq 6$ & 0.5 \\
\hline & & $\begin{array}{l}\mathrm{D} 4.1 \mathrm{~b}-\text { Need elevated hypergolic propellant services (MMH \& } \\
\mathrm{N}_{2} \mathrm{O}_{4} \text { ) loading service at launch point with internal access with } \\
\text { personnel; protective equipment. }\end{array}$ & $\leq 5$ & $\leq 5$ & $\leq 2$ & 1 & $\leq 3$ & $\leq 3$ & $\leq 4$ & 0.5 \\
\hline & & $\begin{array}{l}\text { D4.2 Need multiple Environment Controls System (ECS) services } \\
\left(\text { air/ } / \mathrm{GN}_{2} \text { ) at unique and elevated connection points. }\right.\end{array}$ & $\leq 3$ & $\leq 3$ & $\leq 3$ & 6 & $\leq 5$ & 6 & $\geq 7$ & 0.4 \\
\hline & & $\begin{array}{l}\text { D } 4.3 \text { Need single GHe services at multiple elevated connection } \\
\text { points. }\end{array}$ & $\leq 3$ & $\leq 3$ & $\leq 3$ & 6 & $\leq 5$ & 6 & $\geq 7$ & 0.4 \\
\hline & & $\begin{array}{l}\text { D } 4.4 \text { Need single } \mathrm{GN}_{2} \text { services at multiple elevated connection } \\
\text { points. }\end{array}$ & $\leq 3$ & $\leq 3$ & $\leq 3$ & 6 & $\leq 5$ & 6 & $\geq 7$ & 0.4 \\
\hline & & $\begin{array}{l}\text { D } 4.5 \text { Need multiple special power connections at multiple elevation } \\
\text { points. }\end{array}$ & $\leq 3$ & $\leq 3$ & $\leq 3$ & 6 & $\leq 5$ & 6 & $\geq 7$ & 0.4 \\
\hline & & $\begin{array}{l}\text { D4.6 Need two T-0 Communication connection w/ unique protocol } \\
\text { to KSC LCC (Hardwire) at service connection point near Aft. }\end{array}$ & $\leq 7$ & $\leq 7$ & $\leq 7$ & $\mathrm{n} / \mathrm{a}$ & $\leq 3$ & 6 & 3 & 0.6 \\
\hline & & $\begin{array}{l}\text { D4.7 Need RF comm. (vehicle and P/L RF); antenna hats removed } \\
\text { at launch point. }\end{array}$ & $\leq 3$ & $\leq 3$ & $\leq 5$ & 6 & $\geq 6$ & 6 & $\geq 7$ & 0.5 \\
\hline & & $\begin{array}{l}\text { D4.8 Need manual ordnance installation arming service; } \\
\text { installation and arming at launch point. }\end{array}$ & $\leq 3$ & $\leq 3$ & $\leq 3$ & 1 & $\leq 5$ & 6 & $\leq 3$ & 0.3 \\
\hline & & $\begin{array}{l}\text { D4.9 Need full/flexible payload installation; vehicle environmental } \\
\text { protection; and vehicle repair at launch point. }\end{array}$ & $\leq 3$ & $\leq 3$ & $\leq 3$ & $\leq 6$ & $\leq 6$ & $\leq 3$ & $\leq 6$ & 0.4 \\
\hline & & $\begin{array}{l}\text { D4.10 Need elevated flight crew access with ground emergency } \\
\text { egress capability from launch point. }\end{array}$ & 2 & 2 & 2 & 6 & $\leq 6$ & $\leq 5$ & $\leq 3$ & 0.3 \\
\hline & & Complexity impacts across all services, $\mathbf{C I}_{k}=$ & 0.4 & 0.4 & 0.4 & 0.5 & 0.5 & 0.5 & 0.4 & SSCF $=0.4$ \\
\hline & $\begin{array}{l}\text { D5 - Horizontal } \\
\text { Services required }\end{array}$ & \multicolumn{8}{|c|}{ N/A } & \\
\hline
\end{tabular}

${ }^{8}$ Each service identified is independently supplied to each element, Booster and Orbiter, but share a common interface design.

${ }^{9}$ Maintenance level applies only to ground equipment at launch point for this assessment. Vehicle maintenance level is not applicable for Launch Definition Phase 


\section{NOTES}

${ }^{1}$ McCleskey, C. M., Henderson, E. M., Lepsch, R. A., Rhodes, R. E., Robinson, J. W., "Approach to an Affordable and

Sustainable Space Transportation System," 48th AIAA/ASME/SAE/ASEE Joint Propulsion Conference, AIAA, July 31, 2012.

${ }^{2}$ Dehoff, B., Levack, D. J. H., and Rhodes, R. E., "The Functional Breakdown Structure (FBS) and Its Relationship to Life

Cycle Cost," Technical paper AIAA 2009-5344, presented at 45th AIAA/ASME/SAE/ASEE Joint Propulsion Conference,

Denver, Colorado, 2-5 August 2009.

${ }^{3}$ Wong, G. S., Ziese, J. M., Farhangi, S., Rhodes, R. E., Operationally Efficient Propulsion System Study (OEPSS) Data Book,

Volume IV - OEPSS Design Concepts, NASA Contract NAS10-11568, April 24, 1990.

${ }^{4}$ Ibid.

${ }^{5}$ Bollo, T. R., Garcia, J., McCleskey, C. M., from presentation “Affordability,” presented to NASA Engineering Management

Board (EMB), held at Kennedy Space Center, Florida, 5 June 2012.

${ }^{6}$ Verma, D., (Ph.D), "System Architecture Representation," Stevens Institute of Technology,

http://www.finse.org/2003Spring/presentations/Architecture\%20Representation\%20-\%20FINSE\%20Seminar.pdf, 2003.

${ }^{7}$ Rhodes, R. E., Adams, T. C., McCleskey, C. M., Space Transportation System Availability Requirements and Its Influencing Attributes Relationships, SpaceOps 2008 Conference AIAA, June 2008.

${ }^{8}$ Derived from the FreeDictionary.com, http://www.thefreedictionary.com/Compatibility, June 18, 2012.

${ }^{9}$ Derived from COMNAVAIRFORINST 4790.2B, May 15, 2012.

${ }^{10}$ Advanced Spaceport Technologies Working Group (ASTWG), Baseline Report, November 2003.

${ }^{11}$ KSC Space Transportation System Facility \& Equipment Requirements Documentation Plan, K-STSM-10.1, Revision 1, December 16, 1977.

${ }^{12}$ Advanced Spaceport Technologies Working Group, et al.

${ }^{13}$ Delgado, H. N., "Transforming a Single-use Spaceport to Multi-use," SpaceOps 2012 Conference, August 2012.

${ }^{14}$ Delgado, H. N., McCleskey, C. M., "Adapting New Space System Designs into Existing Ground Infrastructure," SpaceOps 2008 Conference AIAA-2008-3413, Sept 24, 2007.

${ }^{15}$ Advanced Spaceport Technologies Working Group, et al.

${ }^{16}$ Advanced Spaceport Technologies Working Group, et al.

${ }^{17}$ Bollo, T. R., "The Application of an Authority Management Structure to Kennedy Space Center and Cape Canaveral Air Force Station," October 242002.

${ }^{18}$ Ibid.

${ }^{19}$ Space Shuttle Program, Wikipedia, http://en.wikipedia.org/wiki/Space_Shuttle_program, July 1, 2012.

${ }^{20}$ Delgado, H. N., McCleskey, C. M., et al.

${ }^{21}$ Advanced Spaceport Technologies Working Group, et al.

${ }^{22}$ McCleskey, C.M., et al.

${ }^{23}$ Dehoff, B., Levack, D. J. H., and Rhodes, R. E., "The Functional Breakdown Structure (FBS) and Its Relationship to Life Cycle Cost," Technical paper AIAA 2009-5344, presented at 45th AIAA/ASME/SAE/ASEE Joint Propulsion Conference, Denver, Colorado, 2-5 August 2009.

${ }^{24}$ Wong, G. S., et al.

${ }^{25}$ McCleskey, C. M., Henderson, et al.

${ }^{26}$ McCleskey, C. M., Rhodes, R. E., Chen, T. T., and Robinson, J. W., "High-Payoff Space Transportation Design Approach with a Technology Integration Strategy," Technical paper AIAA 2011-5571, presented at 47th AIAA/ASME/SAE/ASEE Joint Propulsion Conference \& Exhibit, San Diego, California, 31 July - 03 August 2011.

${ }^{27}$ McCleskey, C. M., "Space Shuttle Operations and Infrastructure: A Systems Analysis of Design Root Causes and Effects," NASA TP-2005-211519, April 2005.

${ }^{28}$ Delgado, H. N., et al.

${ }^{29}$ Ibid.

${ }^{30}$ George S. W., Waldrop, G. S., Russel E. R., Operationally Efficient Propulsion System Study (OEPSS) Data Book, Volume II - Ground Operations Problems, NASA Contract NAS10-11568, April 24, 1990. 


\section{A Systems Approach to Developing an Affordable Space Ground Transportation Architecture using a Commonality Approach}

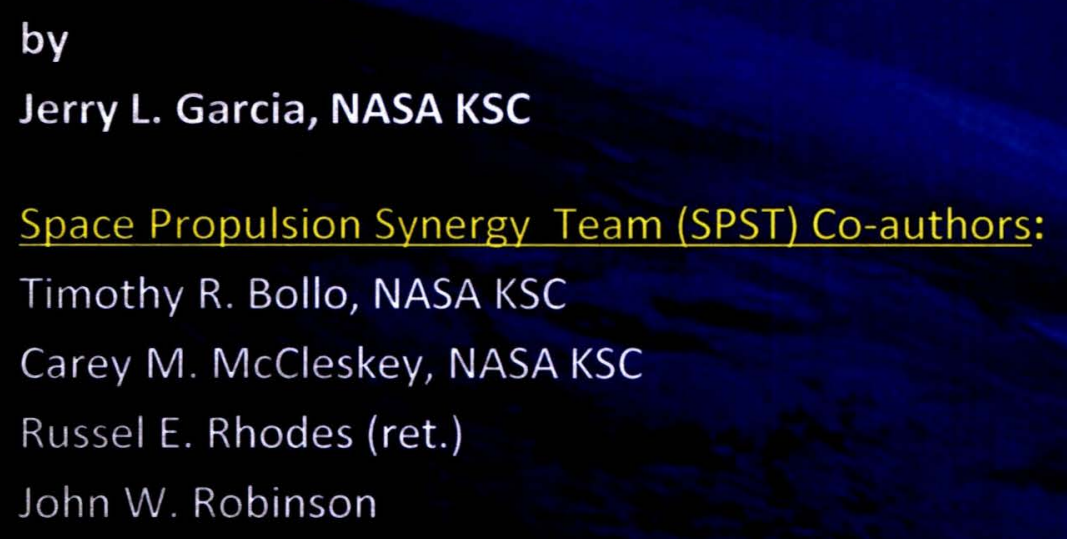




\section{Spaceport Vision and Tenets}

- Spaceport architecture starts by having all stakeholders establish an overall spaceport vision and identifying Design Reference Markets (DRM), as in Step 1 of the initial process

\section{Spaceport Vision}

Enabling affordable and routine access to space through common services, standardized interfaces and simplified operations.

- Architectural tenets align with the overall vision for the spaceport

- These tenets define what is valued by the spaceport architecture:

Tenet-1: Support multiple operators from the same spaceport

Tenet-2: Complement the operator's business model

Tenet-3: Minimize operational constraints especially between operators

Tenet-4: Minimize operator-unique spaceport interfaces and dedicated infrastructure

Tenet-5: Promote commonality, standards, and simplified operations to increase flight rates and improve affordability 
- In order to achieve the Goals from Step 2:

\begin{tabular}{|l|l|c|c|}
\hline \multicolumn{1}{|c|}{ Goal Theme } & \multicolumn{1}{|c|}{ Goal Description } & Mid-term Goals & Long-term Goals \\
\hline Affordability Goal & $\begin{array}{l}\text { Provide a GS Architecture that supports life cycle } \\
\text { cost of less than: }\end{array}$ & $\$ 1,000 / \mathrm{lb}$ & $\$ 100 / \mathrm{lb}$ \\
\hline $\begin{array}{l}\text { Throughput Goal } \\
\text { (Productiveness) }\end{array}$ & $\begin{array}{l}\text { Provide a GS Architecture that supports throughput } \\
\text { per string of assets greater than: }\end{array}$ & $\begin{array}{c}500 \mathrm{MT} / \mathrm{year} \text { per } \\
\text { string of assets }\end{array}$ & $\begin{array}{c}1,000 \mathrm{MT} / \mathrm{year} \text { per } \\
\text { string of assets }\end{array}$ \\
\hline \hline
\end{tabular}

- How to make spaceport infrastructure more affordable? Make it more like an airport

- How do spaceports and airports compare? Both are involved in:

- Dealing with strong interest by: government, public, and commercial entities

- Complex/expensive funding, business, and technical ops in large infrastructure

- Offering services to competing entities that have invested heavily in their operations

- Ensuring safety of operations/surrounding community; maintaining good relations

- There are significant and fundamental differences:

- Airports have a 4-5x magnitude throughput of passengers and aircraft operations per year

- Airports have steady revenue allowing operation as a self-sufficient business

- Airports are less complex, involve mature designs and technologies, and have commonly shared requirements/resources, common services, standard interfaces, and similar infrastructure such as runways and terminals 


\section{Affordability and Commonality at the Spaceport}

- Commonality approach to derive a spaceport ground architecture

- COMMONALITY is the sharing of characteristics or configurations between and within entities for the purpose of improving economic, reliability, and logistic objectives. Impediments to commonality are no existence of:

1. Structured and reliable approaches for developing an affordable ground system compatible with space flight systems

2. Common industry standards between spaceport and vehicle

3. Universal standards between spaceports and vehicles

4. Standard measures for assessing grounds system complexity

5. Standard approaches to developing common spaceport architectures that affordably service multiple vehicles with shared resources from same launch point 
- Process defines four phases for designing a spaceport architecture

- Customer Definition

- Launch Definition

- Veh. Integ. \& Checkout (I\&C) Definition

- Element Recovery \& Production Definition

- Ground services are identified through key architectural decisions addressing key points made during each phase

- Commonality assessments of the services are made across spaceport "station sets"

- STATION SET is the accumulation of facilities, equipment and/or operations to perform a service(s) at

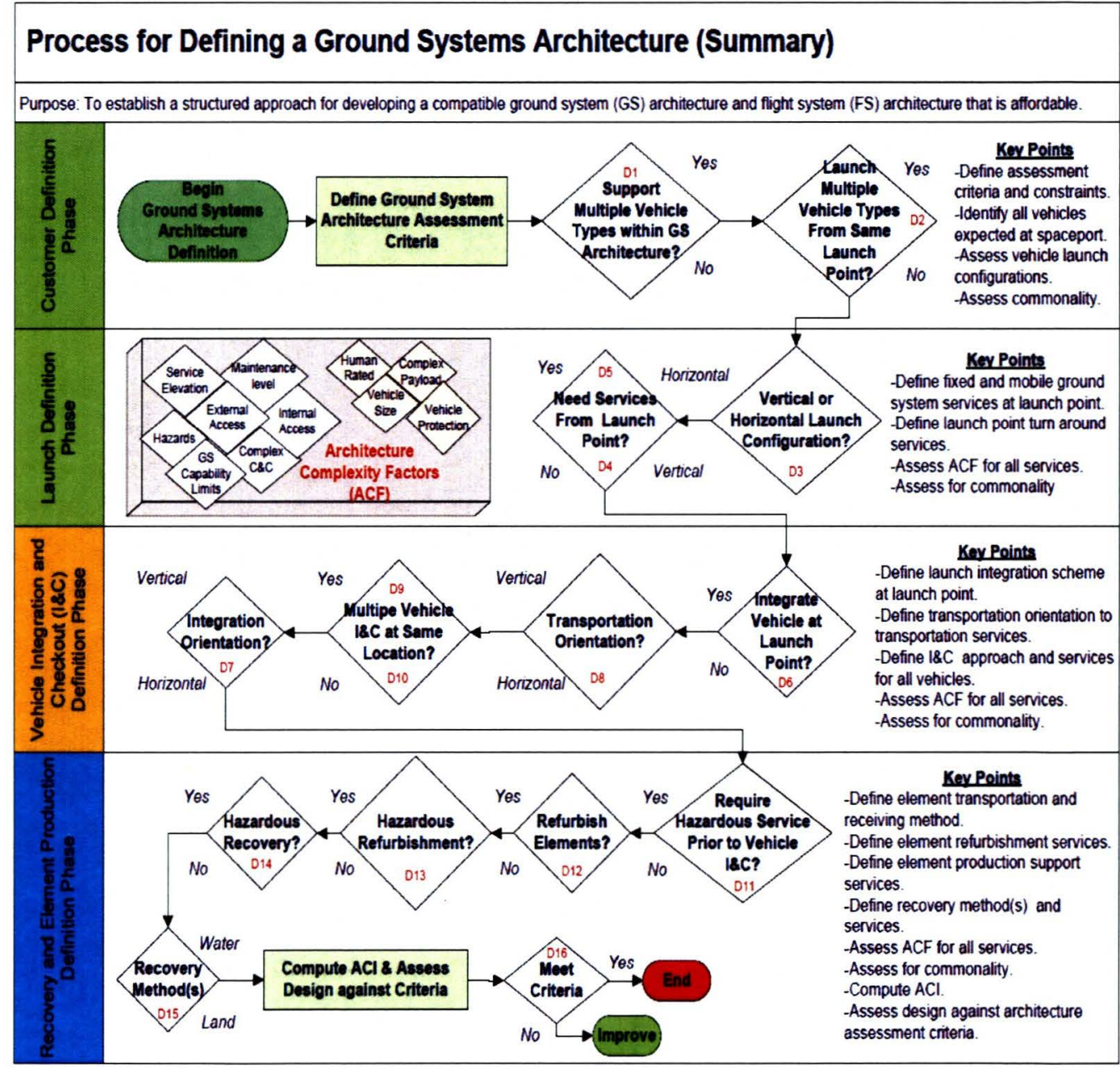
a spaceport. 


\section{Managing Ground Services Complexity} Architectural Complexity Factors (ACFs) and the Architectural Complexity Index (ACI)

\section{Architectural Complexity Factors (ACFs)}

\begin{tabular}{|l|l|}
\hline \multicolumn{1}{|c|}{$\begin{array}{c}\text { Architecture } \\
\text { Complexity Factor }\end{array}$} & \multicolumn{1}{|c|}{ Assessment Focus } \\
\hline $\begin{array}{l}A C F_{1}: \text { Service Elevation } \\
\text { Factor }\end{array}$ & $\begin{array}{l}\text { Assesses the vertical location of the } \\
\text { service. }\end{array}$ \\
\hline $\begin{array}{l}A C F_{2}: \text { External Outer Mold } \\
\text { Line }(\mathrm{OML}) \text { Factor }\end{array}$ & $\begin{array}{l}\text { Assesses the complexity of the OML and } \\
\text { flight access points including integration } \\
\text { of elements and vehicle protection. }\end{array}$ \\
\hline $\begin{array}{l}A C F_{3}: \text { Internal Access } \\
\text { Factor }\end{array}$ & $\begin{array}{l}\text { Assesses the complexity of accessing } \\
\text { internal compartments. This includes } \\
\text { human rated vehicle compartments. }\end{array}$ \\
\hline$A C F_{4}:$ Hazard Type Factor & $\begin{array}{l}\text { Assesses the class of hazard related to } \\
\text { service. }\end{array}$ \\
\hline $\begin{array}{l}A C F_{5}: \text { Command \& Control } \\
(C \& C) \text { Type Factor }\end{array}$ & $\begin{array}{l}\text { Assesses the complexity of command and } \\
\text { control required to support service. }\end{array}$ \\
\hline $\begin{array}{l}A C F_{6}: \text { Maintenance Level } \\
\text { Factor (see Sect. III.A.7) }\end{array}$ & $\begin{array}{l}\text { Assesses the required maintenance level } \\
\text { required. }\end{array}$ \\
\hline $\begin{array}{l}A C F_{7}: \text { Capability Level } \\
\text { Factor }\end{array}$ & $\begin{array}{l}\text { Assesses capability of ground system to } \\
\text { deliver the needed service (e.g., quantity } \\
\text { of a commodity) and its extensibility. }\end{array}$ \\
\hline
\end{tabular}

\section{Architectural Complexity Index (ACI)}

- Used as standard measure for comparing different architectures

- Comparing ACls and ACFs results identifies flight systems burdens on ground systems

- Burdens are made visible early in design phase through differences in $\mathrm{ACl}$ values

- $\mathrm{ACl}$ identifies operational complexities and unique services throughout lifecycle

- These burdens translate into opportunities for improving affordability through commonality

ACF of a service is given by: $S A C F_{i}=\frac{\sum_{k=1}^{7} W F_{k} \times A C F_{i, k}}{\sum_{k=1}^{7} W F_{k} \times \operatorname{MAX}\left(A C F_{i, k}\right)} \quad \begin{aligned} & ; \text { where i=service } \\ & \text { and } k=A C F \text { index }\end{aligned}$ 
- Use common interfaces for common services, such as fluid, gases and electrical

- This approach will lead to simplified operations

- To accommodate different types of vehicle mounts and to minimize MLP redesign impacts, use launch base adapters.

Another example for a vehicle requiring a tower is to:

- Shelter flight-to-ground unique interfaces by adopting a standard structural tower appendage that is movable up and down the face of the tower.

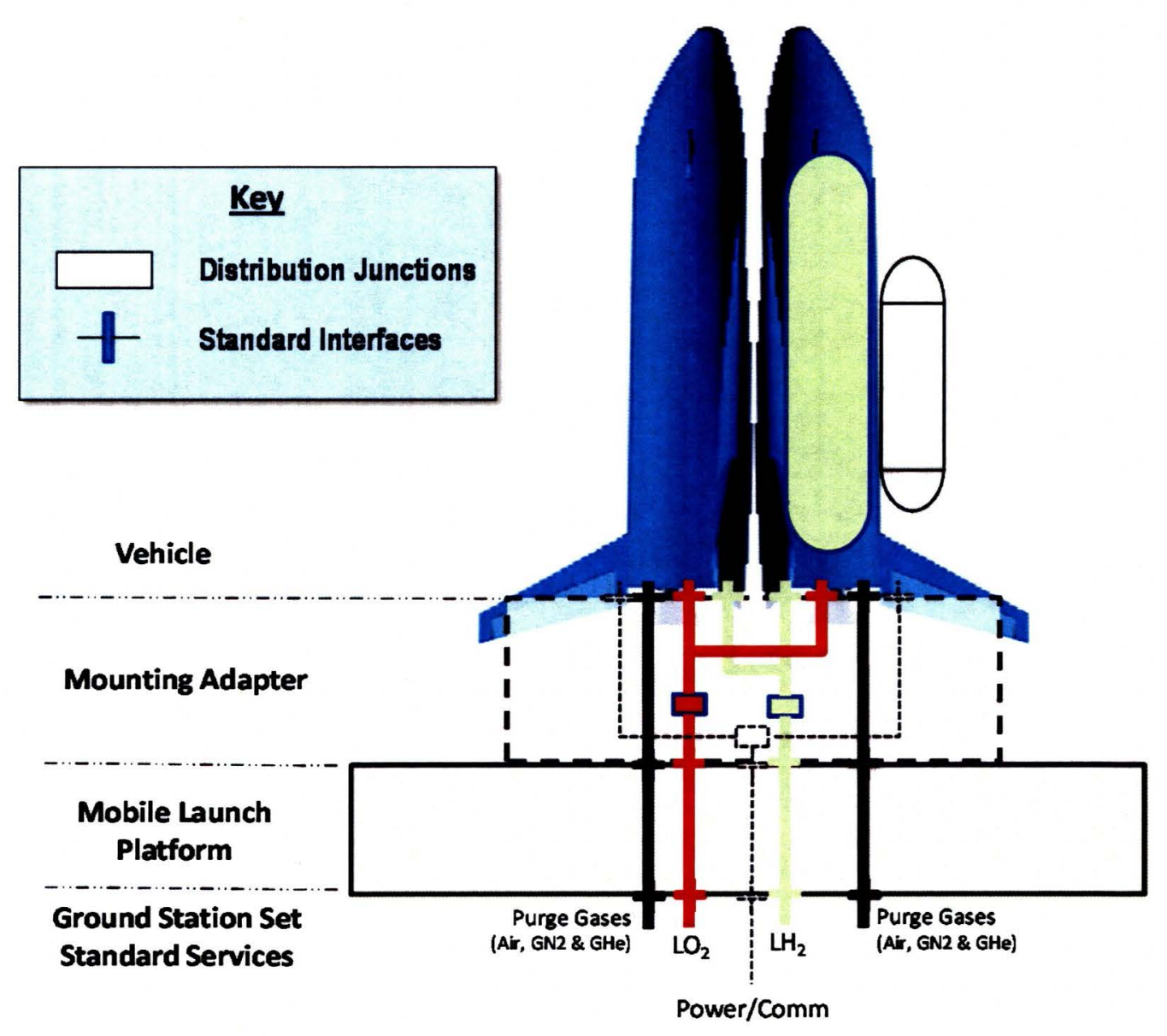




\section{Conclusions}

- A structured approach is available to bring forth viable (i.e., affordable and productive) space transportation architectures

- Examples demonstrated improvement in life cycle affordability and productivity by focusing on operational characteristics, and investments in new design approaches and technologies

- Higher throughput (i.e., more productive) architectures, such as the mostly-reusable examples, have the potential to affordability meet the needs of future markets

- Means for assessing architectural complexity documented (ACFs and $\mathrm{ACl}$ )

- Important to enable affordable and routine access to space through:

Common services, standardized interfaces and simplified operations 